Keywords: $D W P F, S B 6, H g$, ammonia, hydrogen

Retention: Permanent

\title{
Sludge Batch 6/Tank 51 Simulant Chemical Process Cell Simulations
}

D. C. Koopman
D. R. Best

April 2010

Savannah River National Laboratory Savannah River Nuclear Solutions Aiken, SC 29808

Prepared for the U.S. Department of Energy under contract number DE-AC09-08SR22470.

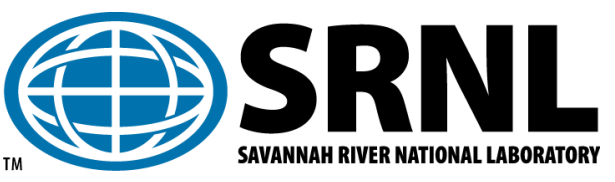


SRNL-STI-2010-00173

Revision 0

\section{DISCLAIMER}

This work was prepared under an agreement with and funded by the U.S. Government. Neither the U.S. Government or its employees, nor any of its contractors, subcontractors or their employees, makes any express or implied:

1. warranty or assumes any legal liability for the accuracy, completeness, or for the use or results of such use of any information, product, or process disclosed; or

2. representation that such use or results of such use would not infringe privately owned rights; or

3. endorsement or recommendation of any specifically identified commercial product, process, or service.

Any views and opinions of authors expressed in this work do not necessarily state or reflect those of the United States Government, or its contractors, or subcontractors.

\section{Printed in the United States of America \\ Prepared for \\ U.S. Department of Energy}




\section{REVIEWS AND APPROVALS}

AUTHORS:

D. C. Koopman, Process Technology Programs

Date

D. R. Best, Engineering Process Development

Date

TECHNICAL REVIEW:

M. E. Stone, Process Technology Programs

Date

APPROVAL:

C. C. Herman, Manager

Date

Process Technology Programs

S.L. Marra, Manager

Date

Environmental \& Chemical Process Technology Research Programs

J. E. Occhipinti, Manager

Date

Waste Solidification Engineering 


\section{EXECUTIVE SUMMARY}

Qualification simulant testing was completed to determine appropriate processing conditions and assumptions for the Sludge Batch 6 (SB6) Shielded Cells demonstration of the DWPF flowsheet using the qualification sample from Tank 51 for SB6 after SRNL washing. It was found that an acid addition window of $105-139 \%$ of the DWPF acid equation (100-133\% of the Koopman minimum acid equation) gave acceptable Sludge Receipt and Adjustment Tank (SRAT) and Slurry Mix Evaporator (SME) results for nitrite destruction and hydrogen generation.

Hydrogen generation occurred continuously after acid addition in three of the four tests. The three runs at $117 \%, 133 \%$, and $150 \%$ stoichiometry (Koopman) were all still producing around $0.1 \mathrm{lb}$ hydrogen $/ \mathrm{hr}$ at DWPF scale after 42 hours of boiling in the SRAT. The $150 \%$ acid run reached $110 \%$ of the DWPF SRAT limit of $0.65 \mathrm{lb} \mathrm{H}_{2} / \mathrm{hr}$, and the $133 \%$ acid run reached $75 \%$ of the DWPF SME limit of $0.223 \mathrm{lb} \mathrm{H}_{2} / \mathrm{hr}$. Conversely, nitrous oxide generation was subdued compared to previous sludge batches, staying below $25 \mathrm{lb} / \mathrm{hr}$ in all four tests or about a fourth as much as in comparable SB4 testing.

Two other processing issues were noted. First, incomplete mercury suspension impacted mercury stripping from the SRAT slurry. This led to higher SRAT product mercury concentrations than targeted $(>0.45 \mathrm{wt} \%$ in the total solids). Associated with this issue was a general difficulty in quantifying the mass of mercury in the SRAT vessel as a function of time, especially as acid stoichiometry increased. About ten times more mercury was found after drying the $150 \%$ acid SME product to powder than was indicated by the SME product sample results. Significantly more mercury was also found in the $133 \%$ acid SME product samples than was found during the SRAT cycle sampling. It appears that mercury is segregating from the bulk slurry in the SRAT vessel, as mercury amalgam deposits for example, and is not being resuspended by the agitators.

The second processing issue was significant ammonium ion formation as the acid stoichiometry was increased due to the high noble metal-high mercury feed conditions. Ammonium ion was found partitioned between the SRAT product slurry and the condensate from the lab-scale off-gas chiller downstream of the SRAT condenser. The ammonium ion was produced from nitrate ion by formic acid. Formate losses increased with increasing acid stoichiometry reaching $40 \%$ at the highest stoichiometry tested. About a third of the formate loss at higher acid stoichiometries appeared to be due to ammonia formation. The full extent of ammonia formation was not determined in these tests, since uncondensed ammonia vapor was not quantified; but total formation was bounded by the combined loss of nitrite and nitrate. Nitrate losses during ammonia formation led to nitrite-to-nitrate conversion values that were negative in three of the four tests. The negative results were an artifact of the calculation that assumes negligible SRAT nitrate losses. The sample data after acid addition indicated that some of the initial nitrite was converted to nitrate, so the amount of nitrate destroyed included nitrite converted to nitrate plus some of the added nitrate from the sludge and nitric acid. It is recommended that DWPF investigate the impact of SME product ammonium salts on melter performance (hydrogen, redox).

It was recommended that the SB6 Shielded Cells qualification run be performed at $115 \%$ acid stoichiometry and allow about 35 hours of boiling for mercury stripping at the equivalent of a $5,000 \mathrm{lb} / \mathrm{hr}$ boil-up rate. 


\section{TABLE OF CONTENTS}

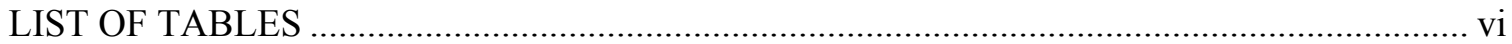

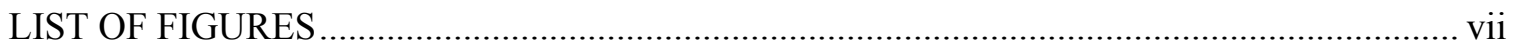

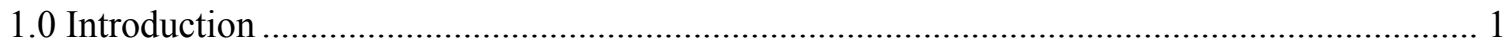

2.0 Summary of Experimental and Analytical Methods ............................................................ 2

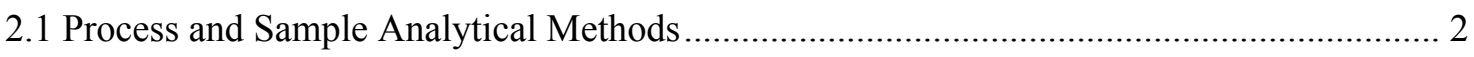

2.2 Simulant Preparation and Characterization..................................................................... 3

2.3 Chemical Process Cell Simulation Details .............................................................................. 5

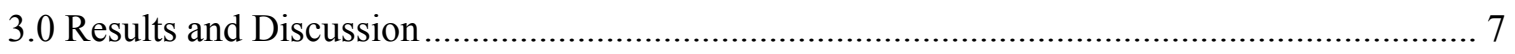

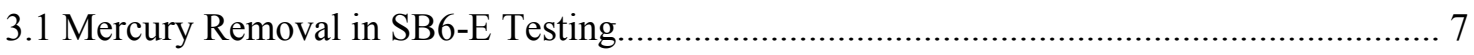

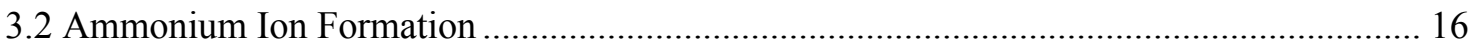

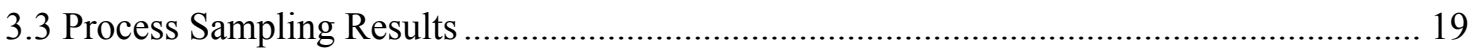

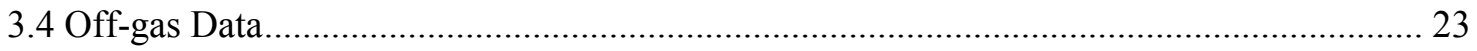

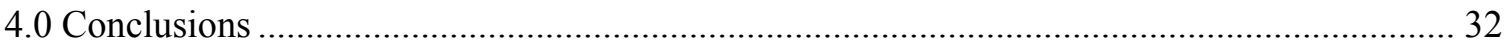

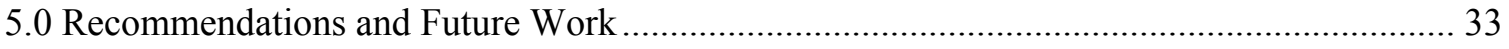

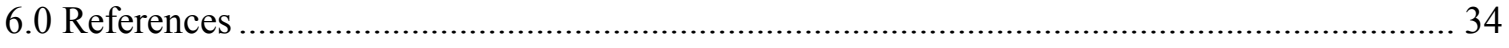

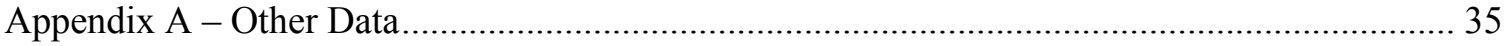




\section{LIST OF TABLES}

Table 1. Selected comparisons of SB6-E to previous qualification batches ................................. 2

Table 2. Elemental composition of simulants calcined at $1100^{\circ} \mathrm{C}, \mathrm{wt} \%$...................................... 4

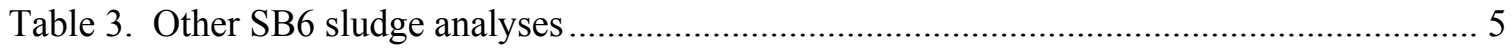

Table 4. Noble metal and mercury concentration comparison .................................................. 5

Table 5. Stoichiometric acid calculation results, moles acid/L slurry ......................................... 6

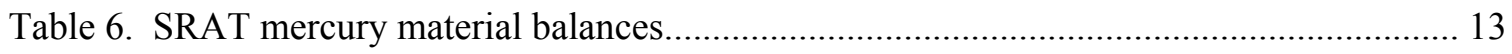

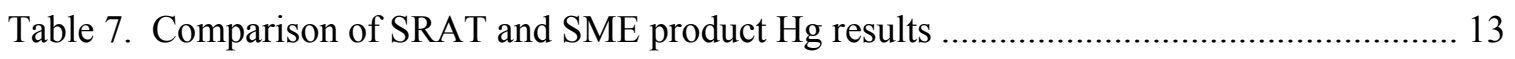

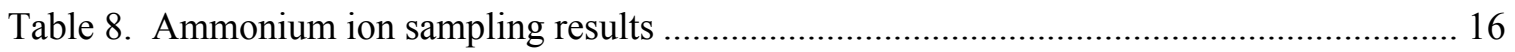

Table 9. Percentages of selected elements in supernate after acid addition ................................ 19

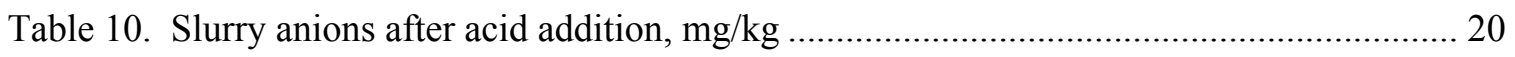

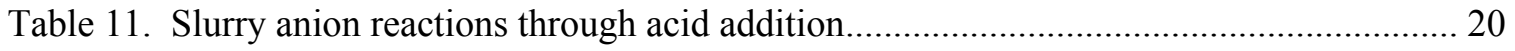

Table 12. Percentages of selected elements in SRAT product supernate .................................... 22

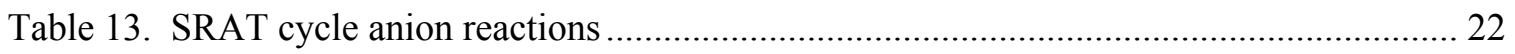

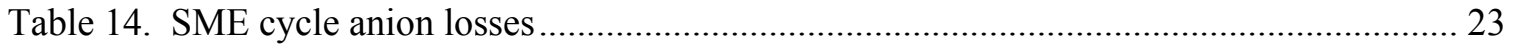

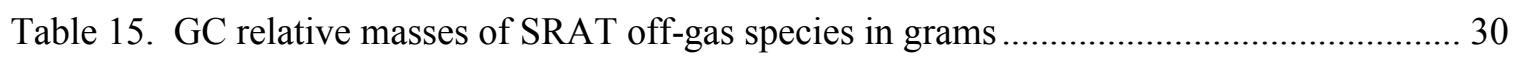

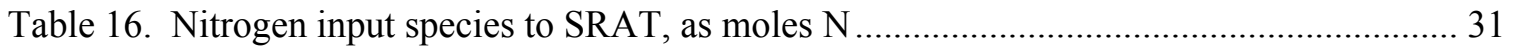

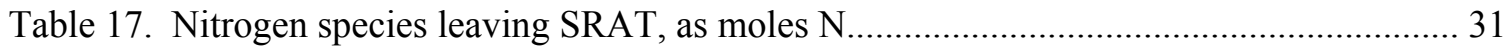

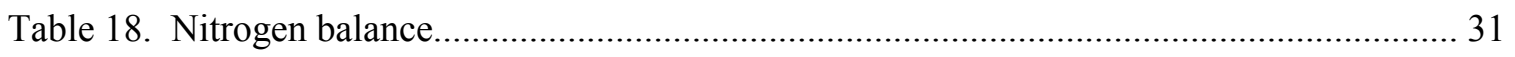

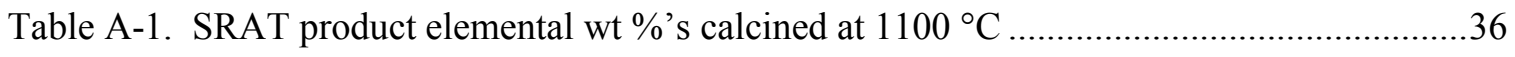

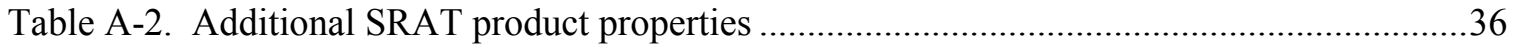

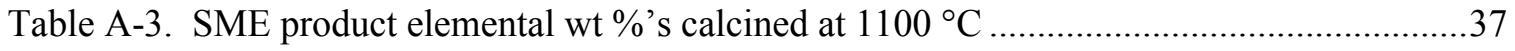

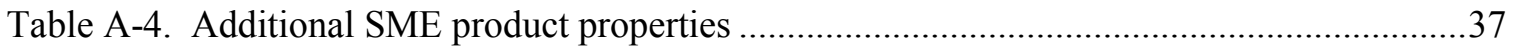




\section{LIST OF FIGURES}

Figure 1. Reduction of $\mathrm{HgO}$ to elemental $\mathrm{Hg}$ during formic acid addition.................................. 8

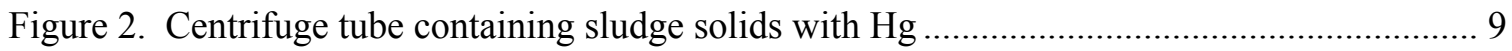

Figure 3. Accumulation of $\mathrm{Hg}$ in MWWT drain during SB6-14 ............................................. 9

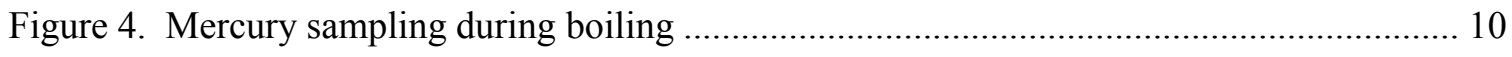

Figure 5. Comparison of sample data to theoretical dewatering ................................................ 11

Figure 6. Comparison of sample data to theoretical stripping rate ............................................ 12

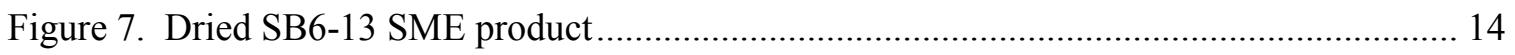

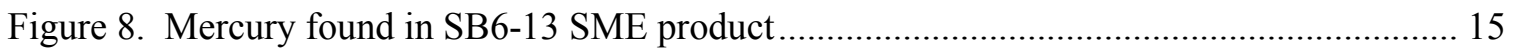

Figure 9. Mercury embedded in dried SME product............................................................. 15

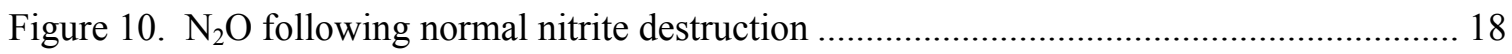

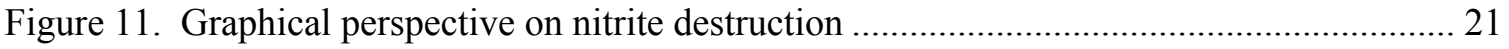

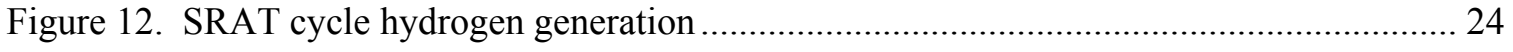

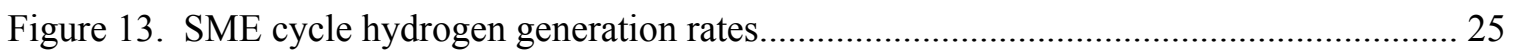

Figure 14. Carbon dioxide during acid addition and dewatering ............................................ 26

Figure 15. Carbon dioxide generation following formic acid addition ...................................... 27

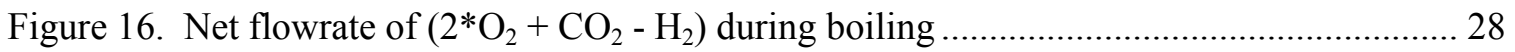

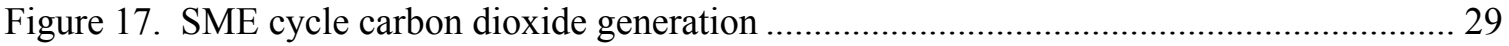

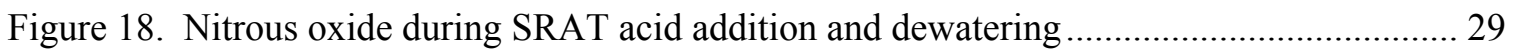

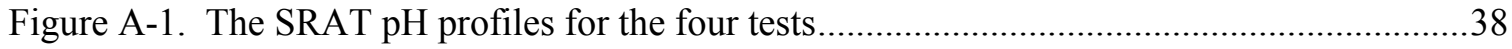

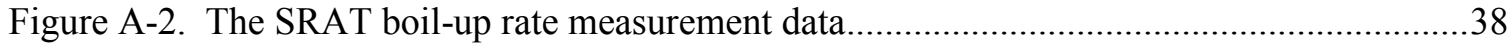

Figure A-3. Oxidation-reduction potential of the SRAT around the time of acid addition...........39 


\section{LIST OF ABBREVIATIONS}

$\begin{array}{ll}\text { ACTL } & \text { Aiken County Technology Laboratory } \\ \text { AD } & \text { Analytical Development } \\ \text { CPC } & \text { Chemical Process Cell } \\ \text { CSTR } & \text { Continuous Stirred Tank Reactor } \\ \text { CV-AA } & \text { Cold Vapor Atomic Absorption } \\ \text { DWPF } & \text { Defense Waste Processing Facility } \\ \text { FAVC } & \text { Formic Acid Vent Condenser (chilled water condenser) } \\ \text { GC } & \text { Gas Chromatography } \\ \text { IC } & \text { Ion Chromatography } \\ \text { ICP-AES } & \text { Inductively Coupled Plasma-Atomic Emission Spectroscopy } \\ \text { MWWT } & \text { Mercury Water Wash Tank } \\ \text { PSAL } & \text { Process Science Analytical Laboratory } \\ \text { REDOX } & \text { Reduction/Oxidation Potential } \\ \text { SB5 } & \text { Sludge Batch 5 } \\ \text { SB6 } & \text { Sludge Batch 6 } \\ \text { SRAT } & \text { Sludge Receipt and Adjustment Tank } \\ \text { SMECT } & \text { Slurry Mix Evaporator Condensate Tank } \\ \text { SME } & \text { Slurry Mix Evaporator } \\ \text { SRNL } & \text { Savannah River National Laboratory } \\ \text { TIC } & \text { Total Inorganic Carbon } \\ \text { TT\&QAP } & \text { Task Technical and Quality Assurance Plan } \\ \text { TTR } & \text { Technical Task Request }\end{array}$


SRNL-STI-2010-00173

Revision 0

\subsection{Introduction}

The Defense Waste Processing Facility (DWPF) will transition from Sludge Batch 5 (SB5) processing to Sludge Batch 6 (SB6) processing in fiscal year 2010. SB6/Tank 51 Chemical Process Cell (CPC) simulations were conducted by the Savannah River National Laboratory (SRNL) using a non-radioactive simulant of the revised SB6/Tank 51 composition based on the August 17, 2009 composition projections for the insoluble solids and November 2009 projections for the supernate (dissolved) solids. The work was conducted to meet the objectives in the Technical Task Request (TTR). ${ }^{1}$ The testing followed the guidelines of a Task Technical and Quality Assurance Plan (TT\&QAP). ${ }^{2}$

The primary justification for the qualification simulant testing was the determination of processing conditions for the Shielded Cells CPC demonstration of the qualification sample of SRNL washed radioactive waste slurry comparable to the SB6/Tank 51 contents. A new SB6 simulant (SB6-E) was prepared for qualification simulant testing. The composition was based on updated analyses of samples from Tank 51 plus revised projections for the wash endpoint. Sludge Receipt and Adjustment (SRAT) cycles were required to evaluate the acid window. Short Slurry Mix Evaporator (SME) cycles were conducted to bound SME cycle hydrogen generation. The SME cycle simulated two frit slurry additions but no canister decontamination water-frit additions. This strategy is considered bounding for hydrogen generation.

Off-gas data were obtained to evaluate hydrogen generation as well as $\mathrm{CO}_{2}$ and $\mathrm{N}_{2} \mathrm{O}$ generation. Profiles of $\mathrm{pH}$ were obtained. Samples were taken following formic acid addition to check for nitrite ion concentration and metal dissolution. Slurry samples were taken after acid addition to monitor the rate of mercury loss from the bulk slurry. Reflux plus dewatering (or total time at boiling) lasted about 42 hours and was done at the scaled DWPF design maximum boil-up rate of $5,000 \mathrm{lbs} / \mathrm{hr}$ of steam.

SB6 is distinct from previous sludge batches in that it contains the highest concentration of mercury in the solids. A comparison to the previous four sludge batches is given in Table 1. The "Acid" row in Table 1 is $100 \%$ of the predicted acid stoichiometry by the current DWPF equation (Hsu/Marek equation), while actual acid is the quantity used in the lab-scale SRAT cycle demonstration. The studied range is given for SB6-E simulant. Additional explanation of row headings follows the table. 
Table 1. Selected comparisons of SB6-E to previous qualification batches

\begin{tabular}{|l|c|c|c|c|c|}
\hline & SB2 & SB3 & SB4 (SC-3) & SB5 (SC-6) & SB6-E \\
\hline Wt\% TS & 18.4 & 27.2 & 19.5 & 17.1 & 14.7 \\
\hline Base, M & 0.308 & 0.577 & 0.316 & 0.739 & 0.589 \\
\hline TIC, mg/kg & 866 & 1,260 & 2,510 & 1,280 & 932 \\
\hline Nitrite, mg/kg & 7,529 & 25,300 & 20,500 & 8,660 & 9,400 \\
\hline $\mathrm{Mn}, \mathrm{wt} \%$ & 3.21 & 3.98 & 1.94 & 3.66 & 6.15 \\
\hline $\mathrm{Hg}, \mathrm{wt} \%$ & 0.195 & 0.0654 & 2.57 & 2.2 & 3.90 \\
\hline $\mathrm{Rh}, \mathrm{wt} \%$ & 0.00777 & 0.0071 & 0.0124 & 0.0250 & 0.0233 \\
\hline $\mathrm{Ru}, \mathrm{wt} \%$ & 0.0332 & 0.0362 & 0.0529 & 0.110 & 0.112 \\
\hline Acid, $\mathrm{mols}^{-\mathrm{L}}$ & 0.751 & 1.63 & 1.30 & 1.32 & 1.185 \\
\hline Actual acid & 0.939 & 2.30 & 1.46 & 1.72 & $1.24-1.87$ \\
\hline
\end{tabular}

$\S$ - acid actually added during SRAT in moles acid/L slurry

$\mathrm{Wt} \% \mathrm{TS}$ is weight percent total solids. Elemental wt\%'s are on a total solids basis. TIC is total inorganic carbon in $\mathrm{mg}$ carbon $/ \mathrm{kg}$ slurry. Base is the equivalent molarity of the slurry titrated to $\mathrm{pH}$ 7. Nitrite is in $\mathrm{mg}$ nitrite/kg slurry. Subsequent analyses indicate that SB6-E was conservative for mercury at $5,730 \mathrm{mg} / \mathrm{kg}$ versus an updated qualification sample result of 4,720 $\mathrm{mg} / \mathrm{kg}$ slurry (82\%). Actual acid in the SB6-E testing varied from $100-150 \%$ of the stoichiometric acid requirement determined using the new Koopman minimum acid equation. (The Koopman minimum acid equation predicted 5\% more acid than the current DWPF acid equation.) Four SRAT/SME simulations were performed. Reports for the historical data are found in the Reference Section. $3,4,5,6$

\subsection{Summary of Experimental and Analytical Methods}

\subsection{Process and Sample Analytical Methods}

The automated data acquisition system developed for the 4-L SRAT rigs was used to collect electronic data on a computer. Collected data included SRAT slurry temperature, bath temperatures for the cooling water to the SRAT condenser and Formic Acid Vent Condenser (FAVC), slurry pH, SRAT mixer speed and torque, air and helium purge flows (He is used as an internal standard and is set to $0.5 \%$ of the nominal SRAT air purge flow). Cumulative acid addition volume data were collected from the automated dispensers using an algorithm that matches the indicated total on the dispenser. All of the tests had a $\mathrm{pH}$ probe in the SRAT slurry to monitor $\mathrm{pH}$. Raw gas chromatography (GC) data were generally acquired on separate computers dedicated to each instrument.

The chilled off-gas leaving the FAVC was passed through a Nafion dryer in counter-current flow with a dried air stream to reduce the moisture content at the GC inlet. Agilent 3000A micro GC's were used on all four runs. The GC's were baked out before and between runs. Column-A can collect data related to $\mathrm{He}, \mathrm{H}_{2}, \mathrm{O}_{2}, \mathrm{~N}_{2}, \mathrm{NO}$, and $\mathrm{CO}$, while column-B can collect data related to $\mathrm{CO}_{2}$ and $\mathrm{N}_{2} \mathrm{O}$. GC's were calibrated with a standard calibration gas containing $0.499 \mathrm{vol} \% \mathrm{He}$, 1.000 vol $\% \mathrm{H}_{2}, 20.00$ vol $\% \mathrm{O}_{2}, 51.511$ vol $\% \mathrm{~N}_{2}, 24.49$ vol $\% \mathrm{CO}_{2}$ and $2.50 \mathrm{vol} \% \mathrm{~N}_{2} \mathrm{O}$. The calibration was verified prior to starting the SRAT cycle and after completing the SME cycle. Room air was used to give a two point calibration for $\mathrm{N}_{2}$. No evidence for $\mathrm{CO}$ generation was obtained while examining the region of the chromatogram where it would elute. 
Process samples were analyzed by various methods. Slurry and supernate elemental compositions were determined by inductively coupled plasma-atomic emission spectroscopy (ICP-AES) at the Process Science Analytical Laboratory (PSAL). Slurry samples were calcined at $1100^{\circ} \mathrm{C}$. The main advantage of this approach is to permit easier comparisons between SRAT product elements and sludge elements. Noble metals and mercury are trimmed uniquely to each SRAT, and their concentrations are known more accurately from material balance considerations than they could be from ICP-AES analyses.

Soluble slurry anions were determined by ion chromatography (IC) on 100-fold weighted dilutions of slurry with water followed by filtration to remove remaining insoluble solids. SRAT cycle, SRAT product, and SME product slurry samples were submitted to Analytical Development (AD) for mercury analysis by cold vapor atomic absorption (CV-Hg). They were also analyzed for $\mathrm{Hg}$ by ICP-AES by PSAL. Sludge samples were submitted to AD for total inorganic carbon analysis of both the starting slurry and the supernate. Starting sludges were analyzed for slurry and supernate density using the Anton-Parr instrument by PSAL. Starting sludges were titrated to $\mathrm{pH} 7$ using the PSAL Mettler-Toledo auto-titrator to determine the base equivalents for input into the stoichiometric acid equation. Dewatering samples were checked for dissolved mercury by CV-Hg. SRAT product slurries and condensates from the SRAT cycle FAVC were analyzed by cation chromatography for ammonium ion by AD.

\subsection{Simulant Preparation and Characterization}

The SB6-E simulant was prepared using the current continuous stirred tank precipitator (CSTR) method. $^{7}$ This method involved the following processing steps:

- A slurry of precipitated $\mathrm{MnO}_{2}$ was prepared.

- An acidic metal nitrate solution was prepared.

- The two were combined and fed to the CSTR along with a $50 \mathrm{wt} \%$ sodium hydroxide solution to produce a caustic slurry of hydrous metal oxide and hydroxide solids in a sodium nitrate solution at a $\mathrm{pH}$ of about 9.5 .

- The slurry was contacted with sodium carbonate to permit conversion of some of the hydroxides to carbonates.

- The slurry was decanted and washed until the nitrate concentration was below the target supernate nitrate concentration.

- The slurry was concentrated to a point consistent with the targeted total solids value for the final slurry.

- Silica, $\mathrm{TiO}_{2}$, and sodium salts were added to complete the preparation.

Table 2 presents the average elemental results of duplicate analyses of two slurry samples from each simulant calcined at $1100^{\circ} \mathrm{C}$. Results for the SB6/Tank 40 Phase II flowsheet simulant studies, that preceded the SB6-E work, and for the SB6 qualification SRAT receipt sample for Shielded Cells run \#9 (SC-9) ${ }^{8}$ are given for comparison. 
SRNL-STI-2010-00173

Revision 0

Table 2. Elemental composition of simulants calcined at $1100^{\circ} \mathrm{C}, \mathrm{wt} \%$

\begin{tabular}{|c|c|c|c|}
\hline Element & $\begin{array}{c}\text { SB6-Phase II } \\
\text { (Tank 40 blend) }\end{array}$ & $\begin{array}{c}\text { SB6-E Simulant } \\
\text { (SB6/Tank 51) }\end{array}$ & $\begin{array}{c}\text { SC-9 } \\
\text { (SB6/Tank 51) }\end{array}$ \\
\hline $\mathrm{Al}$ & 15.3 & 17.0 & 13.9 \\
\hline $\mathrm{Ba}$ & 0.11 & 0.12 & 0.12 \\
\hline $\mathrm{Ca}$ & 1.01 & 0.89 & 0.67 \\
\hline $\mathrm{Ce}$ & 0.07 & 0.11 & 0.18 \\
\hline $\mathrm{Cr}$ & 0.20 & 0.28 & 0.06 \\
\hline $\mathrm{Cu}$ & 0.08 & 0.10 & 0.09 \\
\hline $\mathrm{Fe}$ & 17.4 & 16.6 & 14.9 \\
\hline $\mathrm{K}$ & 0.07 & 0.11 & 0.08 \\
\hline $\mathrm{La}$ & 0.07 & 0.09 & 0.09 \\
\hline $\mathrm{Mg}$ & 0.50 & 0.37 & 0.27 \\
\hline $\mathrm{Mn}$ & 8.02 & 7.93 & 5.28 \\
\hline $\mathrm{Na}$ & 16.7 & 14.9 & 19.6 \\
\hline $\mathrm{Ni}$ & 2.15 & 2.18 & 2.15 \\
\hline $\mathrm{P}$ & $<0.10$ & $<0.10$ & 0.18 \\
\hline $\mathrm{Pb}$ & 0.01 & 0.02 & 0.02 \\
\hline $\mathrm{S}$ & 0.24 & 0.27 & 0.48 \\
\hline $\mathrm{Si}$ & 1.33 & 1.28 & 0.90 \\
\hline $\mathrm{Sn}$ & $<0.01$ & $<0.01$ & $<0.01$ \\
\hline $\mathrm{Ti}$ & $<0.01$ & $<0.01$ & 0.02 \\
\hline $\mathrm{Zn}$ & 0.06 & 0.08 & 0.05 \\
\hline $\mathrm{Zr}$ & 0.03 & 0.28 & 0.20 \\
\hline
\end{tabular}

Aluminum in solution lost during washing explains the $\mathrm{Al} / \mathrm{Fe}$ ratio being higher in the simulant. The usual small differences are seen that are partly due to differences in wash endpoint and to the absence of uranium in the sum of mass percents for the simulants. Removing $U$ and decreasing $\mathrm{Na}$ both tended to make other element percentages higher. That was the case for $\mathrm{Al}, \mathrm{Ca}, \mathrm{Fe}, \mathrm{Mg}$, $\mathrm{Mn}$, and Si in the SB6-E simulant, as well as for some of the minor elements.

Table 3 presents results for total, insoluble, soluble and calcined $\mathrm{wt} \%$ solids, slurry and supernate density, slurry base equivalent molarity, slurry and supernate total inorganic carbon (TIC), and the slurry anion results from IC. 
Table 3. Other SB6 sludge analyses

\begin{tabular}{|l|c|c|c|}
\hline & $\begin{array}{c}\text { SB6-Phase II } \\
\text { (Tank 40 blend) }\end{array}$ & $\begin{array}{c}\text { SB6-E Simulant } \\
\text { (SB6/Tank 51) }\end{array}$ & $\begin{array}{c}\text { SC-9 } \\
\text { (SB6/Tank 51) }\end{array}$ \\
\hline Total solids, wt\% & 16.1 & 14.7 & 15.1 \\
\hline Insoluble solids, wt\% & 10.0 & 9.6 & 9.9 \\
\hline Soluble solids, wt\% & 6.1 & 5.1 & 5.2 \\
\hline Calcined solids, wt\% & 12.3 & 11.4 & 11.9 \\
\hline Slurry density, g/mL & 1.13 & 1.12 & 1.133 \\
\hline Supernate density, g/mL & 1.04 & 1.04 & 1.06 \\
\hline Slurry base equiv., mol/kg & 0.714 & 0.597 & 0.58 \\
\hline \hline Nitrite, $\mathrm{mg} / \mathrm{kg}$ & 10,800 & 9,400 & 10,000 \\
\hline Nitrate, $\mathrm{mg} / \mathrm{kg}$ & 7,345 & 5,460 & 6,840 \\
\hline Sulfate, $\mathrm{mg} / \mathrm{kg}$ & 900 & 1150 & 1200 \\
\hline Oxalate, $\mathrm{mg} / \mathrm{kg}$ & $<100$ & $<100$ & $<100$ \\
\hline Chloride, $\mathrm{mg} / \mathrm{kg}$ & 242 & 175 & $<100$ \\
\hline Slurry TIC, mg/kg slurry & 1,650 & 930 & 913 \\
\hline Supernate TIC, mg/L super & 1,230 & 604 & 827 \\
\hline
\end{tabular}

All SB6-E tests had 3,500 g of starting sludge (before trim chemicals and rinse water). Rh was trimmed as a solution of $\mathrm{Rh}\left(\mathrm{NO}_{3}\right)_{3}$ containing $4.93 \mathrm{wt} \%$ rhodium. $\mathrm{Ru}$ was added as the dry trivalent chloride salt at a purity of $41.73 \mathrm{wt} \% \mathrm{Ru}$. Pd was trimmed as a solution of $\mathrm{Pd}\left(\mathrm{NO}_{3}\right)_{2}$ containing $15.27 \mathrm{wt} \%$ palladium. Silver was added as the dry nitrate salt $\mathrm{AgNO}_{3}$. Mercury was trimmed as dry HgO. Targets for the SB6-E testing are given in Table 4 along with the reported values for the SC-9 SRAT receipt sample ${ }^{8}$ and the earlier SB6 Phase II flowsheet testing ${ }^{12}$.

Table 4. Noble metal and mercury concentration comparison

\begin{tabular}{|l|c|c|c|}
\hline $\begin{array}{l}\text { Wt\% in Dried } \\
\text { Solids }\end{array}$ & $\begin{array}{c}\text { SB6-Phase II } \\
\text { (Tank 40 blend) }\end{array}$ & $\begin{array}{c}\text { SB6-E Simulant } \\
\text { (SB6/Tank 51) }\end{array}$ & $\begin{array}{c}\text { SC-9 } \\
\text { (SB6/Tank 51) }\end{array}$ \\
\hline $\mathrm{Rh}, \mathrm{wt} \%$ & 0.0200 & 0.0233 & 0.0187 \\
\hline $\mathrm{Ru}, \mathrm{wt} \%$ & 0.0943 & 0.1121 & 0.0924 \\
\hline $\mathrm{Hg}, \mathrm{wt} \%$ & 3.50 & 3.90 & 3.12 \\
\hline $\mathrm{Pd}, \mathrm{wt} \%$ & 0.0054 & 0.0066 & 0.0030 \\
\hline $\mathrm{Ag}, \mathrm{wt} \%$ & 0.0135 & 0.0142 & 0.0138 \\
\hline
\end{tabular}

Some of the differences in the wt $\%$ can be attributed to the absence of $U$ and the more washed (lower) Na values of the simulant which led to higher values for the other elements when reported on a percentage basis. In addition Rh and Ru were targeted to $110 \%$ of the projected SC-9 values in the SB6-E simulant.

\subsection{Chemical Process Cell Simulation Details}

The trimmed SRAT receipt volume was about 3.3 L. The 4-L lab-scale SRAT equipment was used for these tests. Four equally spaced stoichiometric factors were used in the four acid calculations, $100 \%, 117 \%, 133 \%$, and $150 \%$. Acid calculations were based on the new Koopman minimum acid requirement equation: ${ }^{9}$ 


$$
\frac{\text { moles acid }}{L \text { slurry }}=\text { base equivalents }+H g+\text { soluble } T I C+1.5 *(C a+M g)+1.0 * \text { nitrite }+1.5 * M n
$$

Acid calculations were also performed using the current DWPF algorithm for comparison: ${ }^{10}$

$$
\frac{\text { moles acid }}{\text { L slurry }}=\text { base equivalents }+2 * \text { total } T I C+0.75 * \text { nitrite }+1.2 * M n+H g
$$

The results of these two calculations for the Phase II (SB6-D) and SB6-E simulants are summarized in Table 5 based on the final SRAT receipt slurry (fully trimmed slurry). The table also includes the actual acid additions made based on $150 \%$ of the Koopman minimum acid equation (maximum acid) and the equivalent DWPF stoichiometric factors (percent) to go from the DWPF acid equation values to the actual acid additions.

Table 5. Stoichiometric acid calculation results, moles acid/L slurry

\begin{tabular}{|l|c|c|c|c|}
\hline & $\begin{array}{c}\text { DWPF Eqn. } \\
\text { moles/L }\end{array}$ & $\begin{array}{c}\text { Koopman Min. } \\
\text { moles/L }\end{array}$ & $\begin{array}{c}\text { Actual addition at } \\
150 \%, \text { moles/L }\end{array}$ & $\begin{array}{c}\text { Equivalent } \\
\text { DWPF factor }\end{array}$ \\
\hline Phase II & 1.397 & 1.466 & 2.199 & $157 \%$ \\
\hline SB6-E & 1.131 & 1.188 & 1.782 & $158 \%$ \\
\hline
\end{tabular}

The Koopman minimum stoichiometric acid equation results were about 5\% higher than the DWPF equation results.

Total acid was partitioned between formic and nitric acids using the latest RedOx equation. ${ }^{11}$ Assumptions of $20-30 \%$ formate loss and $10-0 \%$ nitrite-to-nitrate conversion were also made to enable this calculation to be performed without any prior experience with these simulants (first numbers at $100 \%$, second numbers at $150 \%$, intermediate values for the $117 \%$ and $133 \%$ runs). These assumptions gave the fraction of total acid that was formic acid in the range of 0.87-0.91.

Scaled design basis DWPF SRAT/SME processing conditions were generally used. The SRAT cycle, however, did not have a heel from the prior SRAT batch that is typical of DWPF processing.

- The SRAT air purge scaled to $230 \mathrm{scfm}$ in DWPF.

- A 200 ppm antifoam addition was made prior to nitric acid addition.

- A 100 ppm antifoam addition was made prior to formic acid addition.

- Nitric and formic acid addition were made at $93^{\circ} \mathrm{C}$.

- Acids were added at two gallons per minute scaled from 6,000 gallons to $2.5 \mathrm{~L}$.

- A 500 ppm antifoam addition was made prior to going to boiling following acid addition.

- Boiling assumed a condensate production rate of 5,000 lbs/hr at DWPF scale.

- SRAT dewatering took about 3.2-3.7 hours to produce a $22.5 \mathrm{wt} \%$ total solids slurry.

- Reflux followed dewatering. The end of the 38-hour reflux period defined the end of the SRAT cycle.

- The SME air purge scaled to $74 \mathrm{scfm}$ in DWPF.

- A 100 ppm antifoam addition was made at the start of the SME cycle.

- Two frit-water-formic acid additions were made targeting 34\% waste loading.

- The SME was dewatered following each frit slurry addition. 
- The final SME solids target was $42 \mathrm{wt} \%$ (driven by the equipment configuration).

Six to eight samples were taken during the SRAT cycle to monitor major reactions. It was projected that mercury might exceed the DWPF SRAT product limit after 40 total hours at boiling due to the high starting concentration. Samples were pulled during boiling to monitor suspended and dissolved mercury in the SRAT slurry. These samples were pulled directly into digestion vials to eliminate potential segregation of mercury during sub-sampling/aliquoting steps. The SRAT product slurry was sampled similarly while the vessel contents were still mixing once it had cooled to $90^{\circ} \mathrm{C}$.

Additional SRAT product samples were taken for compositional and solids analyses after the product had cooled further. The Mercury Water Wash Tank (MWWT) and FAVC were drained and the condensates weighed after both the SRAT and SME cycle. The MWWT was temporarily removed from the apparatus after the SRAT cycle, and as much free mercury as possible was collected for weighing. The MWWT was re-installed for the SME but not refilled. The SRAT cycle FAVC condensate was submitted for ammonium ion analysis.

Condensate was collected following the first frit-formic acid slurry addition, and again following the second frit-formic acid slurry addition. SME product mercury samples were pulled using the same protocol as the SRAT product. The SME product then cooled before further samples were pulled. The final SME product samples were taken and the remaining SME product mass was determined. Condensate was drained from the FAVC. Observations were made about elemental mercury in the samples, collected condensates, or on the equipment. A complete SRAT/SME simulation took about 56 hours measured from the start of heating prior to acid addition in the SRAT until the time that the SME product had cooled to less than $50^{\circ} \mathrm{C}$.

\subsection{Results and Discussion}

The sections below summarize the results for off-gas analysis, sample analyses, determination of formate lost and nitrite converted to nitrate, etc. that are typically estimated for CPC simulations. Two issues emerged in the course of testing, however, that are noteworthy and will be discussed first. The two issues were mercury removal and ammonium ion generation. Complete SRAT and SME product analyses, $\mathrm{pH}$ profiles, boil-up rate profiles, and oxidation-reduction probe data were placed in Appendix A.

\subsection{Mercury Removal in SB6-E Testing}

The starting SB6-E sludge solids were trimmed to $3.9 \mathrm{wt} \% \mathrm{Hg}$ prior to SRAT simulations. Partially mitigating this higher than normal value was the moderately low value of $14.7 \mathrm{wt} \%$ total solids of the sludge simulant. The product of the two numbers gives the starting mass fraction of $\mathrm{Hg}$ in the SRAT vessel slurry. An assumed stripping efficiency of $1 \mathrm{~g} \mathrm{Hg} / 750 \mathrm{~g}$ water boiled yielded an estimated stripping time of just over 42 hours at the lab-scale boil-up rate equivalent to $5,000 \mathrm{lb} / \mathrm{hr}$ in DWPF. The boiling time was split approximately into approximately 4 hours of dewatering plus 38 hours of reflux. All four tests had 38 hours of reflux time. The boil-up rate was checked periodically during reflux and was within $\pm 10 \%$ of the target except for a brief period in SB6-15 where it dipped to about $88 \%$ of target.

What was presumably colloidal mercury was observed to form during formic acid addition. A milky layer rose to the surface of the SB6-13 (150\% acid) slurry as the slurry became mildly acidic. It is presumed that elemental mercury droplets larger than the colloidal size range $(<5$ 
microns) would tend to settle rather than form a surface layer. Surface tension forces, however, can stabilize the smaller mercury droplets at the surface. The layer is transient. The mixing patterns tend to draw the layer down into the bulk slurry, while fresh layer area is formed as slurry comes up to the vapor-liquid surface from below. The period that the layer is visible is perhaps ten or fifteen minutes long. At that point, apparently the mercury droplets have coalesced into droplets too large to form a layer, or attached themselves to sludge particles, or the vessel internals, so that the layer disappears.

A somewhat similar though less pronounced layer was seen in SB6-15 (133\% acid). A picture was taken during SB6-15 that captured some of the gray layer floating on the slurry surface (not on the vessel wall) during formic acid addition, Figure 1. The view is looking down into the vessel at about a 45-degree angle.

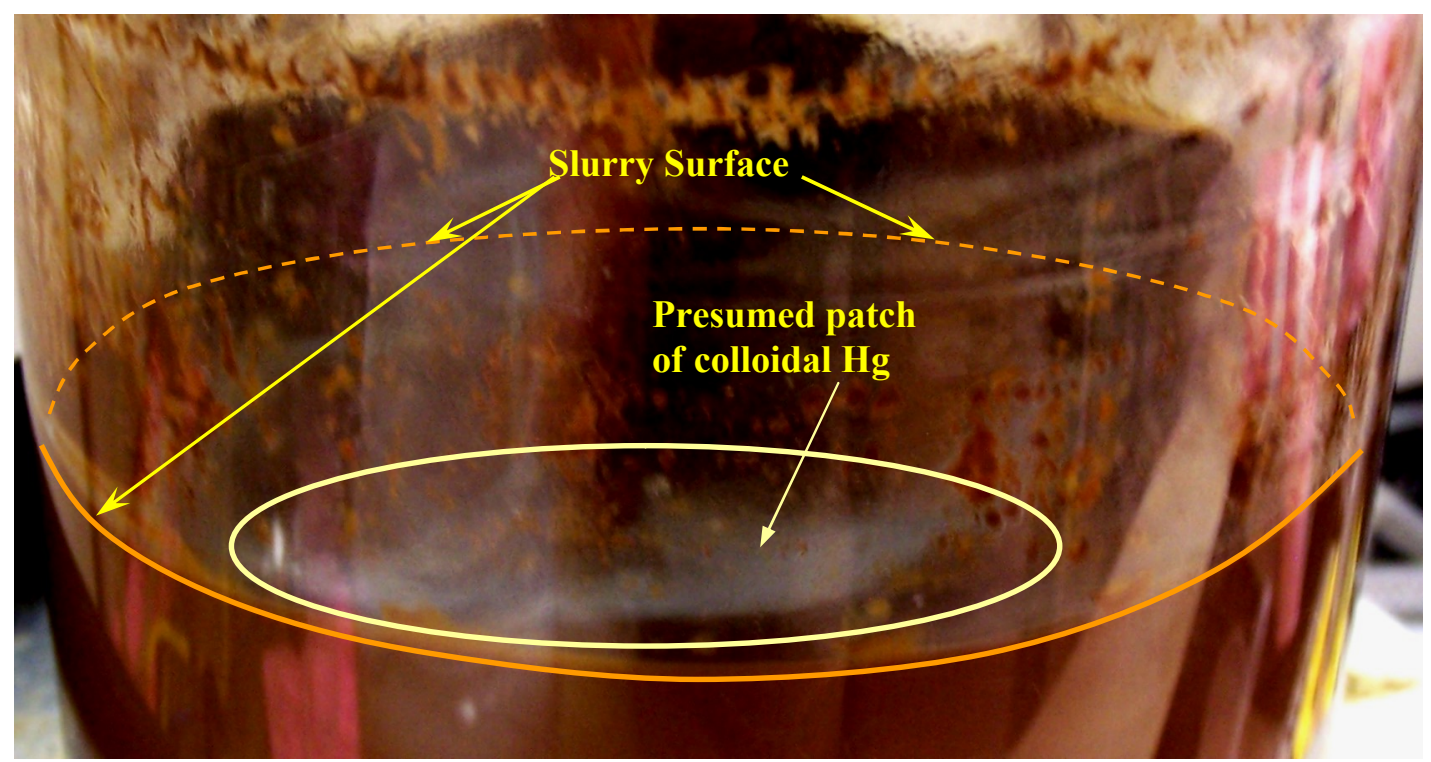

Figure 1. Reduction of $\mathrm{HgO}$ to elemental $\mathrm{Hg}$ during formic acid addition

The insulation on SB6-15 was temporarily removed to take the photograph. It is easy to miss the opportunity to observe the layer because of the insulation that normally blocks the view into the inside. A layer was not observed in the two low acid runs, but this does not mean that one did not form once the slurry became mildly acidic. The layer in the two high acid runs came well before the point when extra acid from the higher stoichiometric factors was added.

Mercury sampling in the $100 \%$ and $150 \%$ acid runs covered the 38 hour SRAT reflux period and occurred at approximately 8 hour intervals. Five individual samples were obtained during reflux at five different times starting immediately after dewatering. Two pairs of additional samples were pulled of the SRAT and SME products. Sample results indicated that $25-36 \%$ of the mercury had already been separated from the bulk slurry before the start of reflux. This degree of separation exceeded that expected for $1 \mathrm{~g} \mathrm{Hg} / 750 \mathrm{~g}$ water boiled. Because of these findings, mercury sampling started immediately after formic acid addition in the $117 \%$ and $133 \%$ acid runs. Sampling during dewatering followed the protocols used for $100 \%$ and $150 \%$ pair.

Slurry samples were taken after formic acid addition and centrifuged to recover the supernate for elemental analysis. The compacted brown sludge solids also appeared to contain dispersed elemental mercury, Figure 2. The finely dispersed mercury appeared as a pale gray haze that was 
somewhat more reflective, or shinier, than the sludge around it and that appeared to be superimposed on the background brown color.

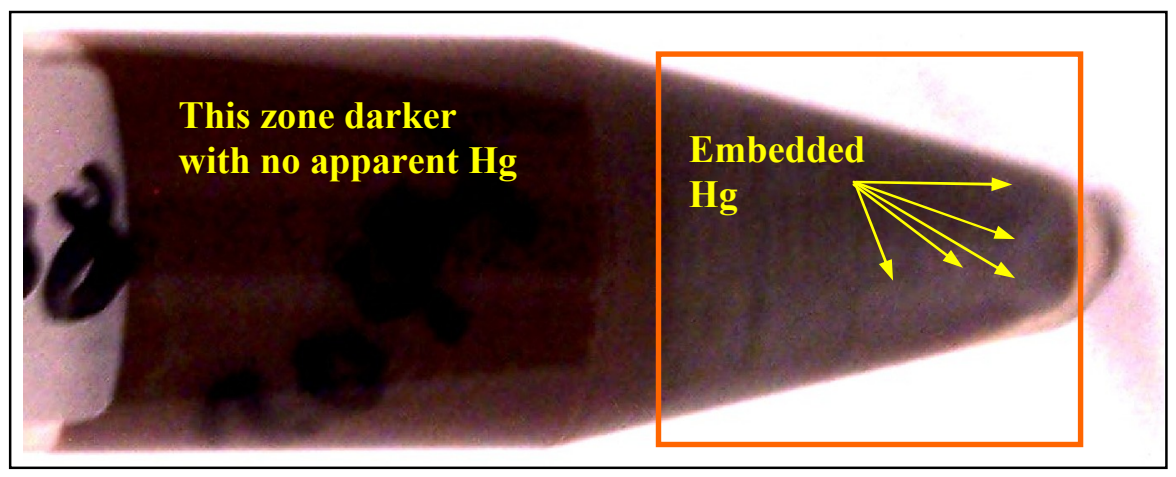

Figure 2. Centrifuge tube containing sludge solids with $\mathrm{Hg}$

The mercury appeared to be enriched toward the bottom (right) end of the centrifuge tube implying that it had settled relatively faster than the average sludge particle (which is what would be expected due to the much higher density of mercury relative to sludge solids). The mercury, as photographed, caused the solids in the bottom of the centrifuge tube to appear lighter and shinier than in the top of the tube. There were no obvious droplets of $\mathrm{Hg}$ visible to the naked eye.

Samples for mercury analysis were pulled directly into digestion vials. The samples were digested with aqua regia and diluted to $100 \mathrm{~mL}$ total volume. The prepared samples were analyzed by both ICP-AES and cold vapor AA (CV-AA). The reported values were converted back to $\mathrm{mg} \mathrm{Hg} / \mathrm{kg}$ final SRAT (or SME) slurry. The two samples taken before dewatering were scaled by the dewatered mass to final SRAT product mass to be on a consistent basis with the others. In other words $\mathrm{mg} \mathrm{Hg} / \mathrm{kg}$ versus time in the SRAT was made graphically equivalent to $\mathrm{g}$ $\mathrm{Hg}$ versus time.

Visual observations supported some degree of successful steam stripping. Small mercury beads formed in the SRAT condenser, dropped into the drain line to the MWWT, and when they reached a certain size, passed from the gently sloped drain line into the MWWT. The Hg collected initially in the center drain leg of the MWWT. Two photos are shown in Figure 3 . The first image was 2.87 hours after formic acid addition was completed, while the second image was 4.25 hours after formic acid completion in run SB6-14 (117\% acid). The actual MWWT drain lines are about half the size of those in the enlarged images below (about $1 / 4$-inch ID).

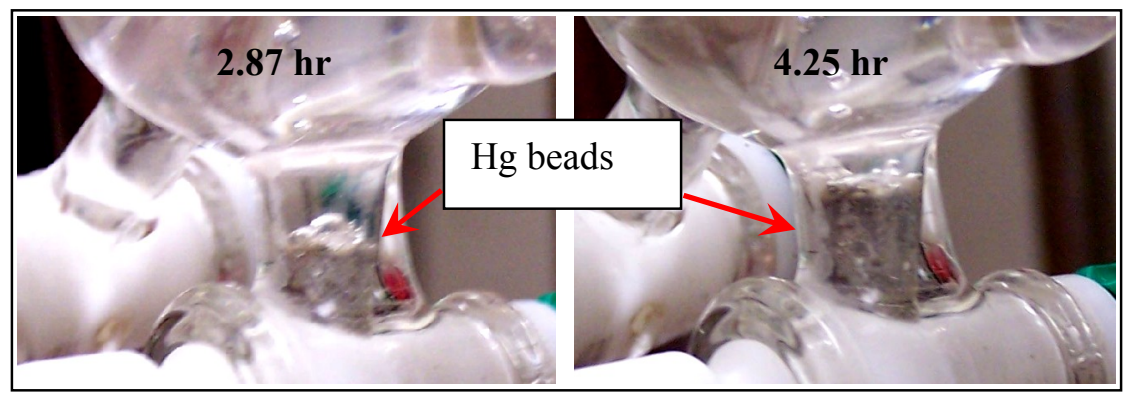

Figure 3. Accumulation of $\mathrm{Hg}$ in MWWT drain during SB6-14 
The mercury being collected in SB6-14 appeared somewhat lumpy at this time (some of this can be seen in the photos), but it became more homogeneous when it was taken out of the MWWT, separated from the condensate, and put in a sample weigh dish. High and low acid runs seemed to accumulate mercury at comparable rates early, but then the high acid runs began to fall behind the low acid runs in terms of the quantity of visual mercury present in the MWWT.

The results of the Hg sampling during boiling in the SRAT are shown in Figure 4.

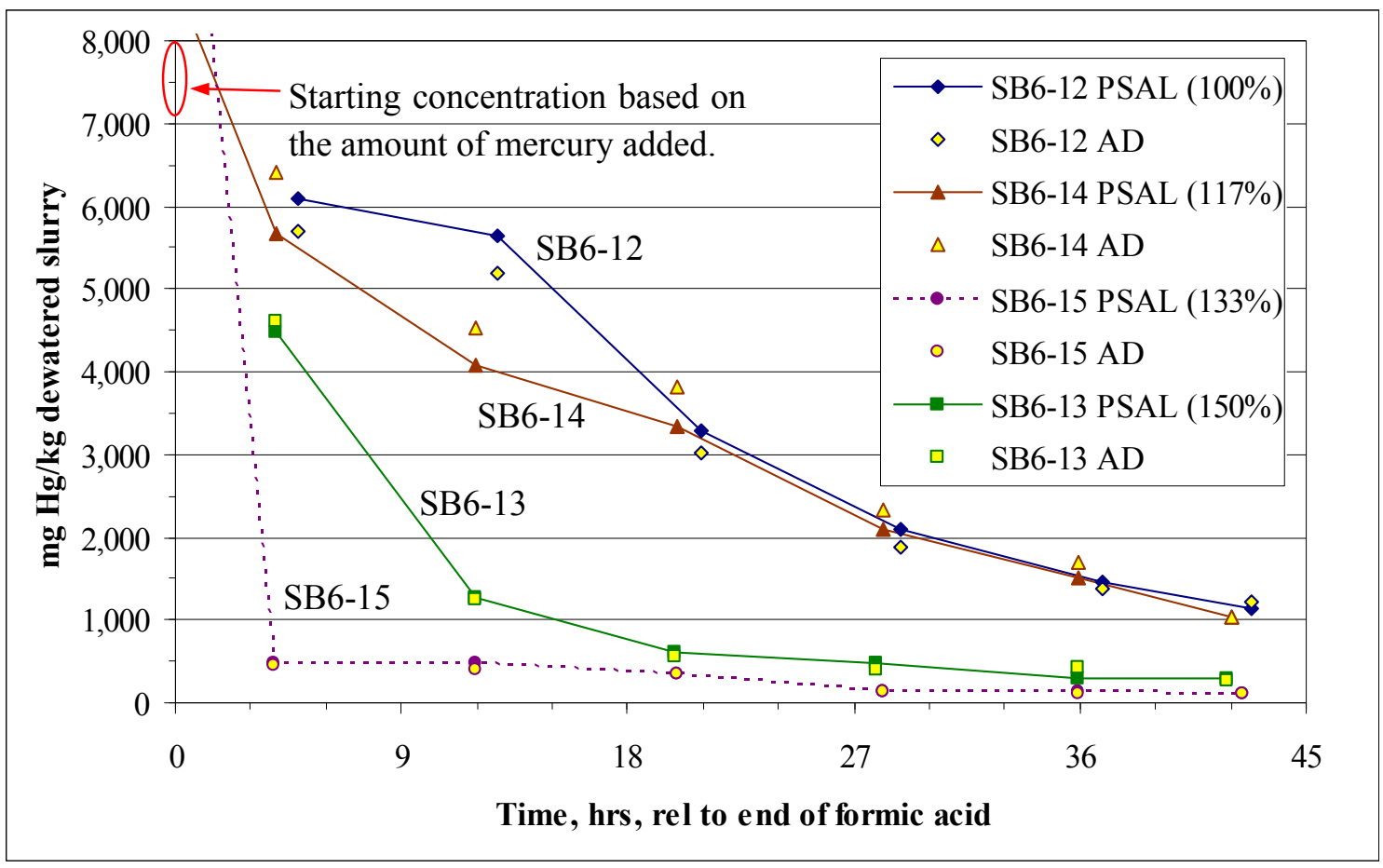

Figure 4. Mercury sampling during boiling

The agreement between the ICP-AES and CV-AA results was generally excellent. The amount of mercury trimmed into the initial sludge adjusted to the post-dewatering mass fell in the range of $7110-7930 \mathrm{mg} \mathrm{Hg} / \mathrm{kg}$ dewatered slurry (depending on acid stoichiometry). The two samples taken after formic acid addition were analyzed by both methods to give higher mercury concentrations than what was added. This suggests that mercury was potentially migrating into the region of the SRAT vessel where the inlet to the sample tube is positioned. An obvious, though potentially erroneous, interpretation of the graphical data is that the two lower acid runs stripped $\mathrm{Hg}$ less efficiently than the two higher acid runs.

Subsequent data and analysis contradict the interpretation of the SRAT sample data that $\mathrm{Hg}$ stripped more rapidly at higher acid stoichiometry. The SB6-15 system (133\% acid) was analyzed first. A maximum theoretical stripping rate was calculated assuming that the elemental mercury was exerting its full vapor pressure into both the air purge and the water vapor created by boiling. 


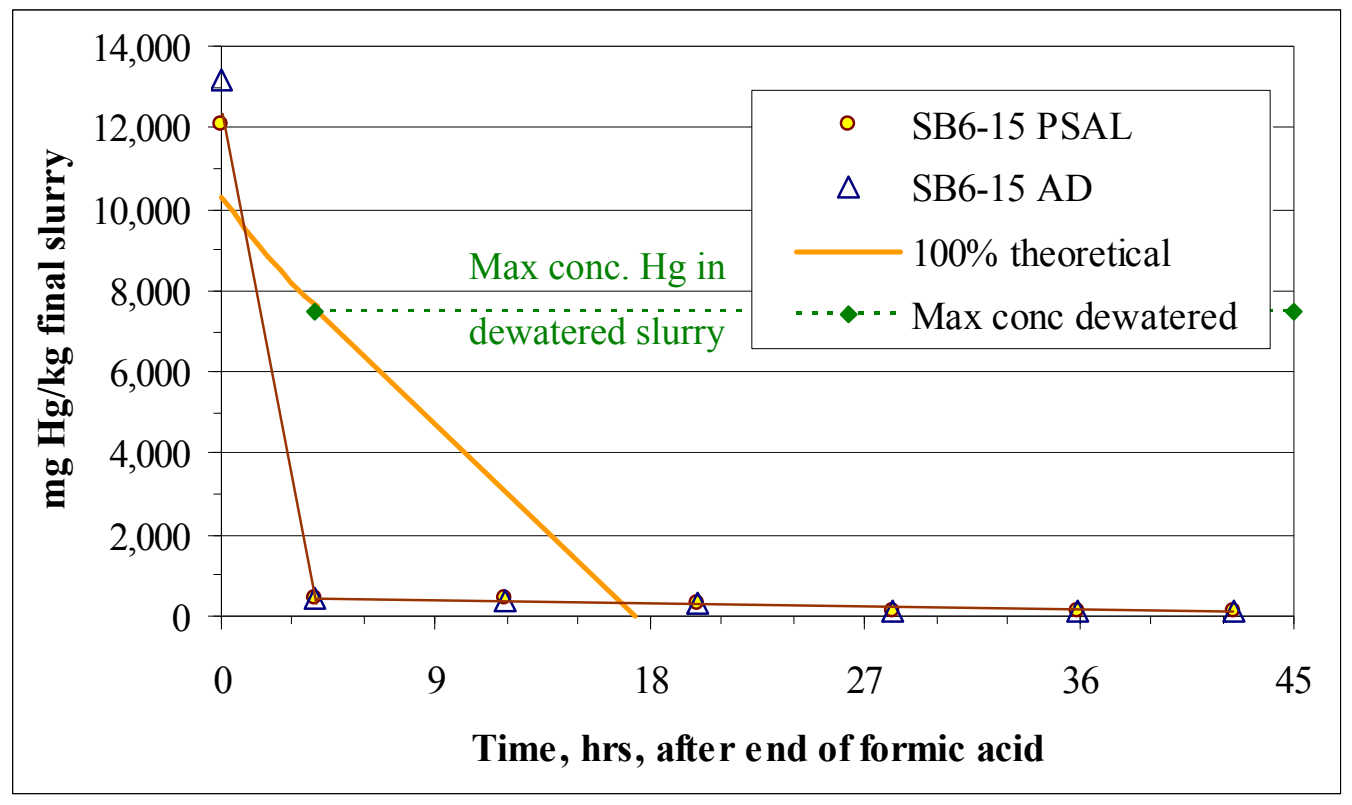

Figure 5. Comparison of sample data to theoretical dewatering

There is a slight curvature to the theoretical curve during dewatering because the $\mathrm{kg}$ of actual slurry relative to the final slurry were changing with time, not because the theoretical stripping rate of mercury was changing. The theoretical curve was arbitrarily put through the point "maximum $\mathrm{Hg}$ in dewatered slurry", "time at end of dewatering". It would shift down slightly if tied to the start of dewatering, but this does not impact the conclusions. The two data points at 4 and 12 hours after formic acid (at least) appear to be thermodynamically unachievable unless mercury is present in some more volatile form than elemental mercury. Alternately, the mercury in the SRAT vessel may no longer be suspended in the bulk slurry. In that case, the sample data curve is actually showing the combined impact of two parallel processes: steam stripping and physical segregation, for example by gravity settling or by formation of mercury-rich deposits separate from the bulk slurry.

SB6-13 (150\% acid) data were analyzed the same way as SB6-15, Figure 6. 


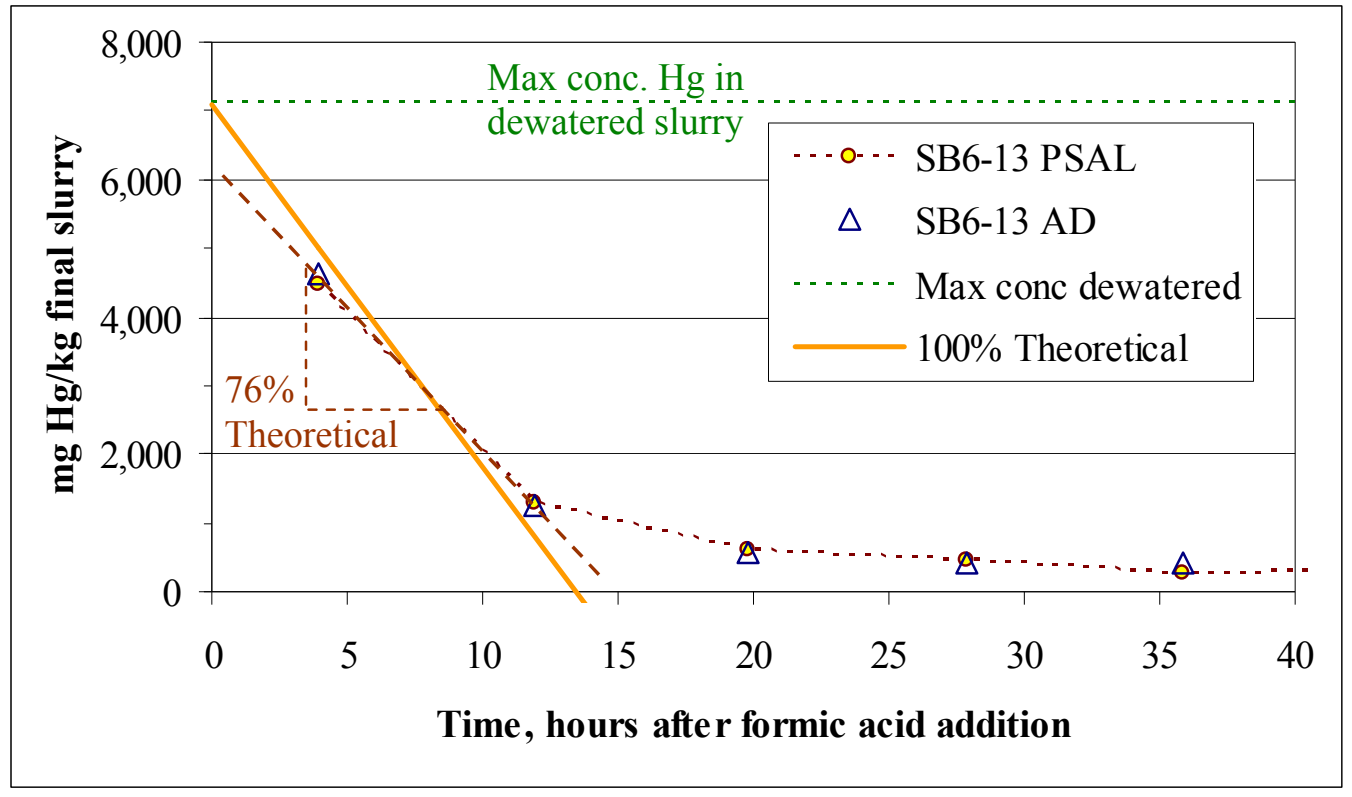

Figure 6. Comparison of sample data to theoretical stripping rate

The slope between the first two data points (at 4 and 12 hours) aligns with about $76 \%$ of the maximum theoretical stripping rate for elemental mercury. While the sample data appear to be overstating the likely actual stripping rate, the analysis is not nearly as conclusive here as for SB6-15. The stripping data for SB6-12 and 14 align generally with $24 \%$ of the theoretical maximum stripping rate. The assumed stripping rate of $1 \mathrm{~g} \mathrm{Hg} / 750 \mathrm{~g}$ steam is apparently close to the $24 \%$ theoretical curve, since SB6-12 and 14 nearly met the $0.45 \mathrm{wt} \% \mathrm{Hg}$ in the SRAT product total solids target. Steam bubbles rising through the lab-scale SRAT, however, do not have as long to come into contact with elemental mercury as steam bubbles rising through the full-scale SRAT. Therefore, the efficiency of gas-liquid contacting in the lab-scale SRAT may not be as high as in the full-scale SRAT (about a 20x difference in linear scale factors associated with being at about $1 / 10,000^{\text {th }}$ scale by volume).

Mass balances on mercury were prepared as part of the SRAT Hg removal analysis. Since SME cycles were performed during these four tests, the SRAT product mass was calculated rather than measured directly. Calculated SRAT product masses are potentially off by $4-5 \%$. Four terms were included in the mercury balance: feed mercury, SRAT product mercury, mercury in the condensate from dewatering, and elemental mercury. The $22.718 \mathrm{~g}$ of $\mathrm{HgO}$ added to each run gave $21.04 \mathrm{~g}$ of elemental $\mathrm{Hg}$ fed. The SRAT product and dewater condensate mercury were obtained by multiplying the appropriate mass and measured $\mathrm{Hg}$ concentration together. Elemental mercury was recovered from the MWWT after the SRAT. Not all of the mercury could be flushed out into the sample bottle, but a relatively high fraction of the visible mercury was recovered. It was then separated from the aqueous condensate and weighed. Mercury material balance results are summarized in Table 6 . 
Table 6. SRAT mercury material balances

\begin{tabular}{|l|c|c|c|c|c|c|}
\hline Run & $\begin{array}{c}\text { Acid } \\
\text { Stoich. }\end{array}$ & $\begin{array}{c}\text { SRAT } \\
\text { Product } \\
\text { Hg, g }\end{array}$ & $\begin{array}{c}\text { Dewater } \\
\text { Condensate } \\
\text { Hg, g }\end{array}$ & $\begin{array}{c}\text { MWWT } \\
\text { elemental } \\
\text { Hg, g }\end{array}$ & $\begin{array}{c}\text { Grams Hg } \\
\text { accounted } \\
\text { for }\end{array}$ & $\begin{array}{c}\text { Percent Hg } \\
\text { accounted } \\
\text { for }\end{array}$ \\
\hline SB6-12 & $100 \%$ & 2.901 & 0.011 & 12.786 & 15.70 & $74.6 \%$ \\
\hline SB6-14 & $117 \%$ & 2.563 & 0.099 & 10.248 & 12.91 & $61.4 \%$ \\
\hline SB6-15 & $133 \%$ & 0.289 & 0.020 & 3.746 & 4.05 & $19.3 \%$ \\
\hline SB6-13 & $150 \%$ & 0.785 & 0.244 & 3.956 & 4.98 & $23.7 \%$ \\
\hline
\end{tabular}

Calculated quantities in the table were carried with digits that were not statistically significant in order to minimize the contribution of round-off errors to the results.

Dissolution of mercury at significant concentrations in the dewatering condensate was not indicated, and in three of the four tests less than $0.5 \%$ of the initial mercury was recovered here. Material balance closure for SB6-12 and 14 was not good, but at least accounted for a majority of the mercury added. The elemental mercury recovered in the two low acid runs appeared to be clean and shiny, and readily merged into a single large mass. Material balance closure for the two high acid runs was poor. The sample data indicated that mercury was leaving the bulk slurry rapidly, but the majority of this mercury was not found in either the dewater condensate or in elemental form in the MWWT. The appearance of the steam-stripped elemental mercury also changed. It was significantly less shiny and remained dispersed into many small droplets. There appeared to be a thin dark film coating some of the droplets that may have been responsible for the mercury appearing less shiny and for the droplets not merging together.

Two SME samples were obtained from each run and digested and analyzed similarly. The total mass of the SME and SRAT product slurries were within 5\% for each of the four tests. The SME product mass essentially consisted of $25 \%$ frit and $75 \%$ concentrated SRAT product. SME and SRAT product results are compared in Table 7. The SME concentration on a frit-free basis would be roughly $4 / 3$ as high as given in the last column.

Table 7. Comparison of SRAT and SME product Hg results

\begin{tabular}{|l|l|c|c|c|c|}
\hline Run & Acid & $\begin{array}{c}\text { SRAT } \\
\mathrm{mg} \mathrm{Hg} / \mathrm{kg}\end{array}$ & $\begin{array}{c}\text { SRAT } \\
\mathrm{wt} \% \text { in TS }\end{array}$ & $\begin{array}{c}\text { SME } \\
\mathrm{mg} \mathrm{Hg} / \mathrm{kg}\end{array}$ & $\begin{array}{c}\text { SME } \\
\mathrm{wt} \% \text { in TS }\end{array}$ \\
\hline SB6-12 & $100 \%$ & 1155 & $0.505 \%$ & 660 & $0.149 \%$ \\
\hline SB6-14 & $117 \%$ & 1025 & $0.460 \%$ & 876 & $0.194 \%$ \\
\hline SB6-15 & $133 \%$ & $\mathbf{1 1 4}$ & $\mathbf{0 . 0 5 1 \%}$ & $\mathbf{9 8 5}$ & $\mathbf{0 . 2 1 9 \%}$ \\
\hline SB6-13 & $150 \%$ & 282 & $0.134 \%$ & 214 & $0.050 \%$ \\
\hline
\end{tabular}

SB6-15 results are believed to understate the mercury present at the end of the SRAT cycle; see discussion below.

SB6-12, 13, and 14 data indicated continued removal of mercury from the bulk slurry during the SME cycle. Continued stripping was definitely anticipated for SB6-12 and 14 due to the relatively high $\mathrm{Hg}$ concentrations still present at the start of the SME cycle. A small quantity of visible elemental mercury was seen in the collected condensate bottles from dewatering in the SME, but this could have been mercury that was held-up in the equipment from the SRAT cycle rather than freshly formed during the SME cycle. The same equipment is used in the SME cycle as the SRAT cycle, but the MWWT is drained at the end of the SRAT cycle, and the MWWT 
becomes an extension of the Slurry Mix Evaporator Condensate Tank (SMECT) during the SME cycle.

SB6-15 data indicated significantly more mercury in the vessel following the SME cycle than was present in the end of the SRAT samples. Since no additional mercury was added, the results imply that the SRAT sample(s) may have been low in $\mathrm{Hg}$ (there were essentially seven digestions in SB6-15 that were comparable to each other and lower than the two SME results). The SRAT steam stripping curve The two SME samples were pulled in the same way as the SRAT cycle samples (for all four runs). The technicians also noted droplets of mercury in the bottom of the vessel after pouring out the bulk SME slurry from SB6-15. This observation could indicate that the SME sample Hg results are actually low (rather than high if the SRAT results were accepted as representative). The observation of mercury on the bottom of the SME would be expected to correlate with low measurements if some of the mercury was not suspended at the time of sampling.

There is sufficient evidence of significant residual mercury in the SB6-15 SME cycle to reject the SB6-15 SRAT sample data results as tracking steam stripping of mercury from the vessel and nothing else. One potential explanation is that mercury fell to the bottom of the SRAT during the SRAT cycle (or otherwise segregated from the bulk slurry). When frit was added, it brought some of the mercury back into the bulk slurry permitting it to be detected in the samples. This mechanism was most pronounced in SB6-15, because most of the mercury segregated quickly (hypothetically based on Figure 4) early in the SRAT cycle, and consequently there was more residual mercury for the frit to help resuspend.

Six weeks after the SRAT/SME testing, the SME product from SB6-13 (highest acid) was taken, poured into two brownie pans, and dried to a crumbly mass, Figure 7, to support increased $\mathrm{Pu}$ loading testing.

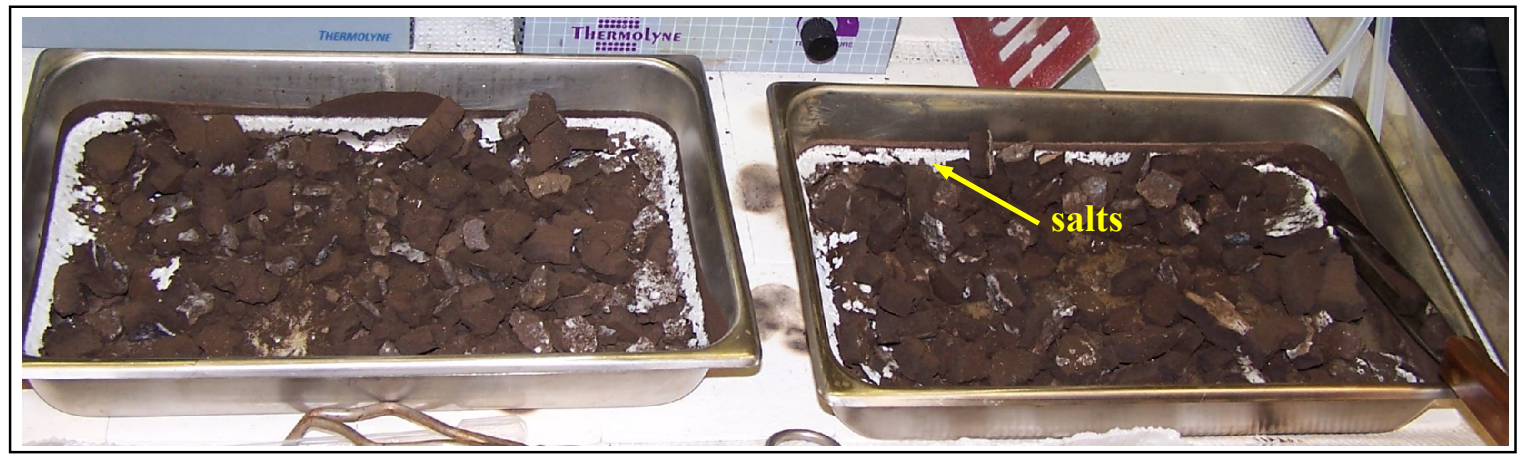

Figure 7. Dried SB6-13 SME product

The white material around the edges of the two pans consists of precipitated sodium salts from the supernate. When the dried SME product was broken up and pieces were turned over, there was a lot of mercury found as fine beads embedded in the dried solids. More $\mathrm{Hg}$ was found in the left pan, which had been filled with the bottom half of the contents in the SME product carboy. A half dozen or so distinct $\mathrm{Hg}$ beads (larger than those embedded in the solids) had disengaged from the dried SME product. An enlarged section of the left pan is shown below, Figure 8 . 


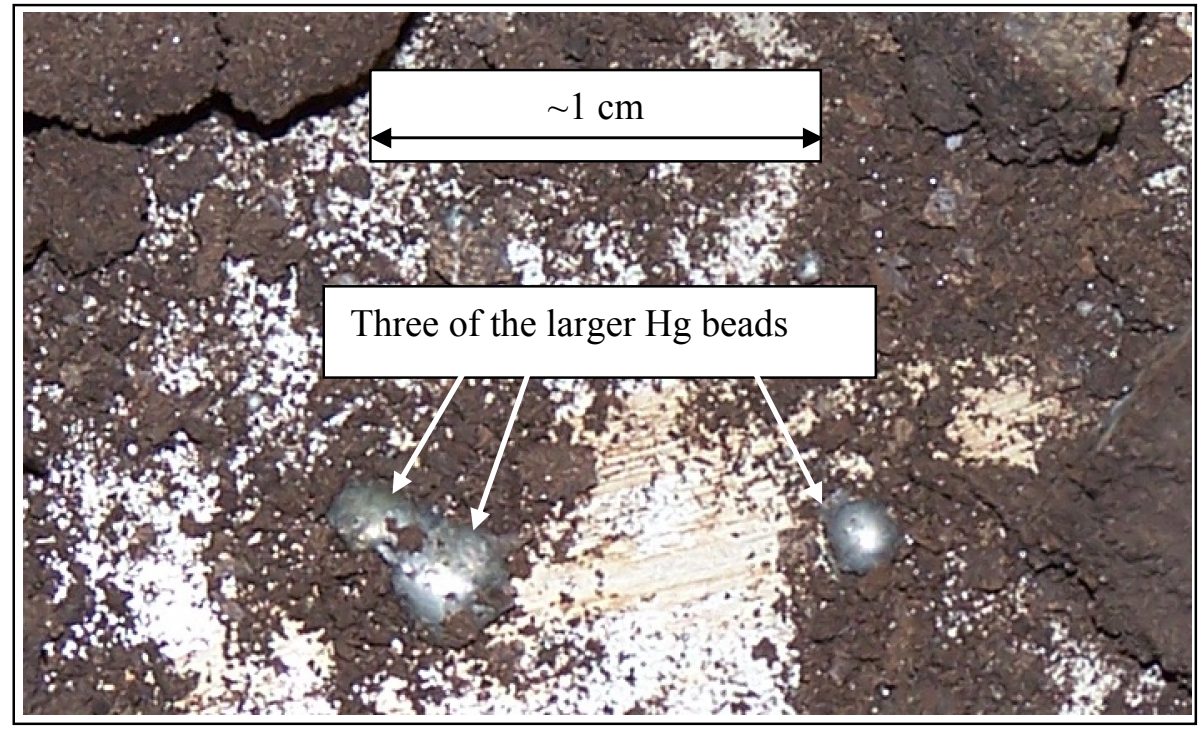

Figure 8. Mercury found in SB6-13 SME product

There were dozens (perhaps hundreds) of smaller beads of mercury embedded in the undersides of the pieces of dried SME product. A relatively extreme case is shown in Figure 9. Arrows were used to indicate some of the larger embedded beads (smaller embedded beads were also present, but did not show up clearly in the photographs).

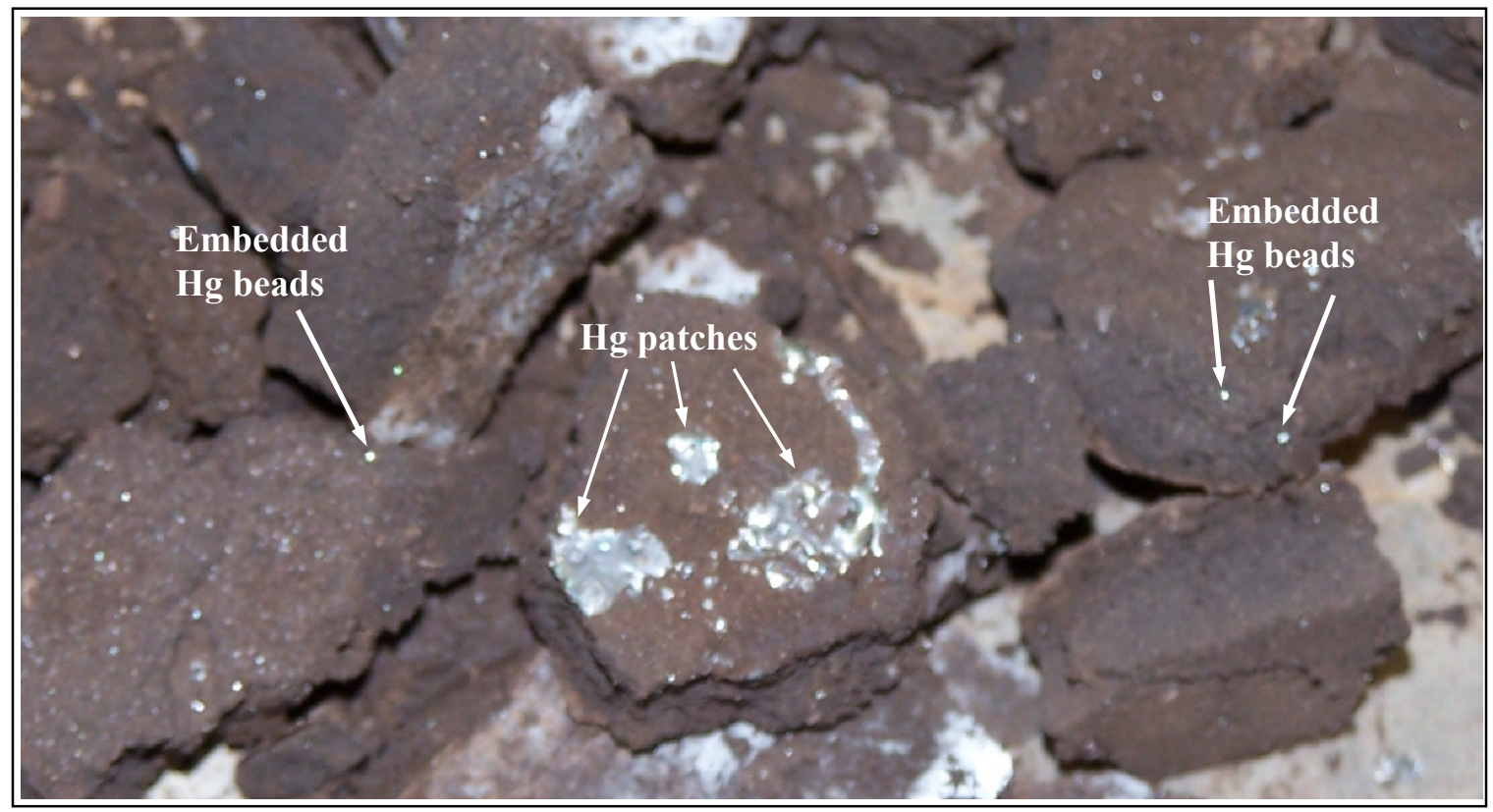

Figure 9. Mercury embedded in dried SME product

The piece in the center of Figure 9 had patches of mercury on it in addition to embedded beads. The piece is about a half inch across. The free mercury was collected from the beads in the pan, along with a bit of fine dust from the frit-sludge dried solids, and a weight of 4 grams was obtained. The concentration in Table 7 combined with the SME product mass gives a total mercury mass of $0.58 \mathrm{~g}$ for SB6-13. The pan result apparently indicates that at least 3 grams of 
$\mathrm{Hg}(>15 \%$ of initial total) had segregated from the bulk slurry, and consequently had not been sampled via the SRAT vessel sample tube.

The issues with SB6-13 and 15 discussed above may be related to rheology. Higher acid simulant runs tend to be less viscous than lower acid runs. The settling rate of a given size mercury bead is higher in a lower viscosity system. Mercury may be more prone to separate from the slurry and collect on the bottom as acid stoichiometry increases. Mixing velocities may not have been high enough to resuspend larger $\mathrm{Hg}$ droplets once they formed and migrated to the bottom of the vessel. Such droplets in DWPF are supposed to collect in the SRAT or SME mercury sump. The $\mathrm{Hg}$ sample data in Figure 4 is more likely to be a graph of the combined effects of mercury removal by steam stripping coupled with mercury removal from the bulk slurry by gravity-driven settling. An alternative hypothesis is that the lower $\mathrm{pH}$ after acid addition in the higher stoichiometry runs permits the mercury to segregate due to alterations in surface charges, or the presence of additional dissolved cations, or the formation of fresh precipitates in those runs once $\mathrm{pH}$ begins to rise, or due to some other feature tied to higher acid stoichiometry.

\subsection{Ammonium Ion Formation}

Ammonium ion was found in the SB6 Phase II flowsheet study ${ }^{12}$ SRAT run at $150 \%$ acid stoichiometry. The SRAT product slurry had a concentration of $1,390 \mathrm{mg} / \mathrm{L}$ and the accumulated condensate in the FAVC had a concentration of $3,240 \mathrm{mg} / \mathrm{L}$. The ammonium ion found this way was equivalent to a $20 \%$ loss of the nitrate in the sludge, trim chemicals, and nitric acid used in this test. The $103 \%$ acid run had just $7 \mathrm{mg} / \mathrm{L}$ in the FAVC condensate and was not sampled further. Continued sampling for ammonium was included in the SB6-E qualification simulant testing based on the Phase II findings.

Sample results from the SB6-E simulant testing are summarized in Table 8. Results were sorted by increasing acid stoichiometry. Also included is the percentage of the ammonium ion found in the SRAT product versus the FAVC.

Table 8. Ammonium ion sampling results

\begin{tabular}{|l|c|c|c|c|}
\hline Run & Acid & $\begin{array}{c}\text { SRAT Product, } \\
\mathrm{mg} / \mathrm{L}\end{array}$ & $\begin{array}{c}\text { FAVC, } \\
\mathrm{mg} / \mathrm{L}\end{array}$ & $\begin{array}{c}\text { Ammonium in } \\
\text { SRAT Prod. }\end{array}$ \\
\hline SB6-12 & $100 \%$ & n.a. & 465 & - \\
\hline SB6-14 & $117 \%$ & 324 & 9,580 & $72.2 \%$ \\
\hline SB6-15 & $134 \%$ & 507 & 12,100 & $72.6 \%$ \\
\hline SB6-13 & $150 \%$ & 825 & 12,400 & $88.2 \%$ \\
\hline
\end{tabular}

Two-thirds to three-quarters of the identified ammonium ion mass was in the SRAT product, but this was less than in the Phase II high acid test where $96 \%$ was in the SRAT product. The transfer of one-quarter to one-third of the ammonium from the SRAT to the FAVC as ammonia vapor makes the question of how much additional ammonia vapor went out the off-gas line more relevant than what was indicated by the Phase II test. The Phase II test was only boiled for slightly more than half as long as the qualification simulant tests. The extended boiling may have promoted transfer of the ammonia from the SRAT to the FAVC. The longer boiling also allowed the $\mathrm{pH}$ to rise further in the SB6-13 to 15 runs. The Phase II- $150 \%$ acid SRAT vessel was at $\mathrm{pH}$ 6.4 at the end of boiling, while SB6-13 to 15 SRAT vessels had reached 6.7-7.0 at the end of 
boiling. An ammonia scrubber has subsequently been installed in the lab-scale off-gas line to absorb the volatile ammonia for analysis.

Negative nitrite-to-nitrate conversions were calculated for SB6-13 to 15. Values are given in Table 13, Section 3.3. The ammonium ion that was detected in SB6-13 to 15 corresponded to 8$16 \%$ of the nitrate in the starting SB6-E sludge, trim chemicals, and added nitric acid (not counting nitrate formed during nitrite destruction).

The formation of ammonia from nitrate is presumed to be a multi-step reaction with the overall stoichiometry below:

$$
5 \mathrm{HCO}_{2} \mathrm{H}+\mathrm{NO}_{3}^{-} \rightarrow \mathrm{NH}_{3}+\mathrm{HCO}_{2}^{-}+4 \mathrm{CO}_{2}+3 \mathrm{H}_{2} \mathrm{O}
$$

An equivalent, alternate form of this equation more appropriate for lower $\mathrm{pH}$ values is:

$$
4 \mathrm{HCO}_{2} \mathrm{H}+\mathrm{HNO}_{3} \rightarrow \mathrm{NH}_{3}+4 \mathrm{CO}_{2}+3 \mathrm{H}_{2} \mathrm{O}
$$

In either case, nitrate to ammonia conversion is a reduction reaction. Nitrogen goes from the +5 oxidation state in nitrate to the -3 oxidation state in ammonia (net change in oxidation state of eight). This is consistent with the conversion of four formic acid molecules to $\mathrm{CO}_{2}$, with a change of two in nitrogen oxidation state for each formic acid molecule destroyed. Literature articles have the nitrate adsorbing onto a catalytic substrate where the oxygen atoms are sequentially stripped and then replaced with hydrogen atoms. The initial overall reaction above can be broken down into at least three sequential reactions:

$$
\begin{aligned}
& \mathrm{HCO}_{2} \mathrm{H}+\mathrm{NO}_{3}^{-} \rightarrow \mathrm{NO}_{2}^{-}+\mathrm{CO}_{2}+\mathrm{H}_{2} \mathrm{O} \\
& 3 \mathrm{HCO}_{2} \mathrm{H}+2 \mathrm{NO}_{2}^{-} \rightarrow 2 \mathrm{NO}+2 \mathrm{HCO}_{2}^{-}+\mathrm{CO}_{2}+2 \mathrm{H}_{2} \mathrm{O} \\
& 5 \mathrm{HCO}_{2} \mathrm{H}+2 \mathrm{NO} \rightarrow 2 \mathrm{NH}_{3}+5 \mathrm{CO}_{2}+2 \mathrm{H}_{2} \mathrm{O}
\end{aligned}
$$

These three reactions sum to the overall reaction above (after dividing through by two). The middle reaction is one of the three reactions normally written for nitrite destruction in the SRAT cycle. In any case, the proposed mechanism has nitrate ion, nitrite ion, neutral NO, and neutral $\mathrm{NH}_{3}$ adsorbed on the catalyst in sequence as the nitrate is converted to $\mathrm{NH}_{3}$. Not all destroyed nitrate ion must end up as $\mathrm{NH}_{3}$. Some of the nitrate could desorb from the catalyst as nitrite ion, $\mathrm{NO}$, or even $\mathrm{N}_{2}$, potentially as:

$$
2 \mathrm{HCO}_{2} \mathrm{H}+2 \mathrm{NO} \rightarrow \mathrm{N}_{2}+2 \mathrm{CO}_{2}+2 \mathrm{H}_{2} \mathrm{O}
$$

Liberation of nitrite ion, $\mathrm{NO}$, or $\mathrm{N}_{2}$ from the catalyst would represent nitrate lost but not converted into ammonia. Contemporary research is focused on developing catalysts for treating nitrate and nitrite waste waters that selectively promote $\mathrm{N}_{2}$ formation over $\mathrm{NH}_{3}$ formation. These papers indicate that simple catalysts generally produce a mixture of both species from adsorbed NO.

The current GC in the off-gas line is capable of observing episodes of nitrite destruction to $\mathrm{N}_{2} \mathrm{O}$ that might arise if fresh nitrite is formed after the regular period of sludge nitrite destruction. The current $\mathrm{GC}$ can also observe the behavior of $\mathrm{CO}_{2}$ as a function of time. If the current air purge were replaced with an 80:20 Argon- $\mathrm{O}_{2}$ purge, then it would also be possible to monitor for 
nitrogen evolution. The current $\mathrm{GC}$ can observe NO, but $\mathrm{NO}$ is often absorbed into the condensing water vapors in the SRAT condenser during dewatering and reflux and does not reach the GC.

$\mathrm{N}_{2} \mathrm{O}$ formation was observed following the regular period of nitrite destruction in SB6-13, 14, and 15. The periods of $\mathrm{N}_{2} \mathrm{O}$ generation did not follow any clear pattern with acid addition, but the rates of production were comparable to that seen in the one Phase II flowsheet run that made significant ammonium ion.

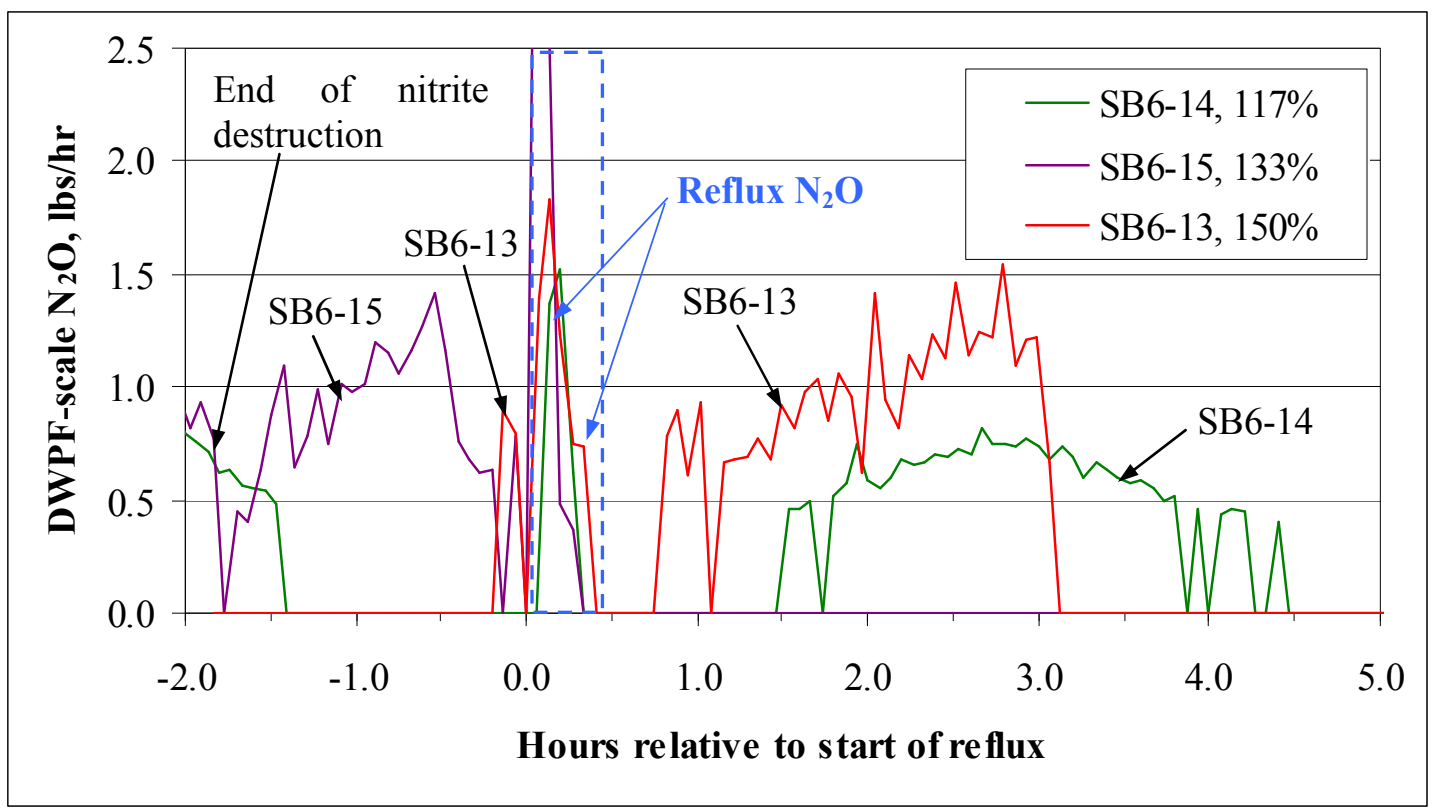

Figure 10. $\mathrm{N}_{2} \mathrm{O}$ following normal nitrite destruction

Rates of order $1 \mathrm{lb} \mathrm{N}_{2} \mathrm{O} / \mathrm{hr}$ were achieved in three runs as shown above. The peaks just after the onset of reflux are normally seen, and are due to the return of a small amount of nitrite from the MWWT at the beginning of reflux. Some small $\mathrm{N}_{2} \mathrm{O}$ production was seen about 39 hours after formic acid addition in SB6-12, the 100\% acid run, which may be significant to ammonium ion production at the low acid end of the window (not shown on graph). Rates of about $0.2 \mathrm{lbs}$ $\mathrm{N}_{2} \mathrm{O} / \mathrm{hr}$ were achieved sporadically until the end of the SRAT cycle in SB6-12 (about three hours with $\mathrm{N}_{2} \mathrm{O}$ alternating being above and below the detection limit of the GC).

No solid explanation is available for why the SB6-15 additional $\mathrm{N}_{2} \mathrm{O}$ came before reflux, while the SB6-13 and 14 extra $\mathrm{N}_{2} \mathrm{O}$ came after, although it looks as though SB6-13 may have been starting just prior to reflux, and then the onset of reflux caused a delay of about 45 minutes. It is possible, however, that it is tied into the behavior of the mercury (since ammonium production became an issue in testing sludge batches with high mercury and noble metal concentrations). Another potential factor is the $\mathrm{pH}$, which may be impacting the adsorption of nitrite on the catalyst. The high acid tests have had apparent issues with mercury segregation (or some alternative loss mechanism) that are not predictable, but that may relate to the timing of the ammonium and $\mathrm{N}_{2} \mathrm{O}$ formation.

Several SME cycle condensates from the three higher acid stoichiometry runs were available for follow-up analyses. The ammonium ion results indicated considerable transfer of ammonia from 
the SME vessel into the off-gas system where it was absorbed into the condensing water vapor in the SME condenser. SB6-14 (117\% acid) first frit addition dewatering condensate had ammonium equivalent to $17 \%$ of the SRAT product ammonium ion mass. SB6-15 (133\% acid) first and second frit and final dewatering condensates had ammonium equivalent to $41 \%$ of the mass found in the SRAT product. SB6-12 (150\% acid) first and second frit and final dewatering condensates had ammonium equivalent to $33 \%$ of the mass found in the SRAT product. The first SB6-12 SME cycle condensate had 1,080 $\mathrm{mg}$ ammonium/L, which was the highest concentration seen in the SME dewatering condensates. Presumably the SME cycle had additional ammonium ion formation in parallel with the stripping of ammonia into the off-gas system, but the data do not permit further quantification of the timing or rate of formation.

The presence of ammonium ion in the slurry supernate, rather than ammonia gas, raises questions concerning the role of ammonium ion that reaches the DWPF melter. The two principal questions appear to be:

- How much of the ammonium ion is thermally decomposed to hydrogen?

- Does ammonium ion act as another reductant in parallel with formic acid?

It is recommended that DWPF perform a technical evaluation of these potential impacts to melter behavior.

\subsection{Process Sampling Results}

Samples were pulled following acid addition to characterize the slurry anion and supernate cation concentrations. Table 9 gives the percentages of initially insoluble significant elements in the simulant that partially dissolved during acid addition. The $\mathrm{pH}$ at the end of acid addition is also given as a benchmark, since some of the solubilities are believed to be driven by supernate $\mathrm{pH}$.

Table 9. Percentages of selected elements in supernate after acid addition

\begin{tabular}{|l|l|r|r|r|r|r|r|r|r|r|c|}
\hline & Acid & $\mathrm{Ca}$ & $\mathrm{La}$ & $\mathrm{Mg}$ & $\mathrm{Mn}$ & $\mathrm{Ni}$ & $\mathrm{Rh}$ & $\mathrm{Ru}$ & $\mathrm{S}$ & $\mathrm{Zn}$ & $\mathrm{pH}$ \\
\hline SB6-12 & $100 \%$ & 94 & 2 & 37 & 49 & 15 & 80 & 11 & 64 & 4 & 4.8 \\
\hline SB6-14 & $117 \%$ & 113 & 3 & 43 & 73 & 30 & 95 & 17 & 72 & 9 & - \\
\hline SB6-15 & $133 \%$ & 111 & 6 & 49 & 82 & 38 & 103 & 22 & 71 & 14 & 4.4 \\
\hline SB6-13 & $150 \%$ & 115 & 10 & 57 & 84 & 42 & 34 & 20 & 69 & 23 & 3.8 \\
\hline
\end{tabular}

1 - The $\mathrm{pH}$ probe in SB6-14 did not hold calibration.

The species $\mathrm{La}, \mathrm{Mg}, \mathrm{Mn}, \mathrm{Ni}$, and $\mathrm{Zn}$ showed increasing solubility with increasing acid stoichiometry (decreasing $\mathrm{pH}$ ), consistent with the results from the recent SRAT chemistry study, except for Mg. The previous SRAT chemistry testing with a simulant made with $\mathrm{Mg}(\mathrm{OH})_{2}$ showed nearly complete $\mathrm{Mg}$ dissolution prior to the end of acid addition that persisted into the reflux period. SB6-E simulant contains precipitated $\mathrm{Mg}$ salts, which were presumed to be $\mathrm{Mg}(\mathrm{OH})_{2}$, but which may be a mixture of multiple species. La is not always included in simulant recipes, so the partial La dissolution data add another piece to the understanding of SRAT chemistry.

The original SB6-E simulant was analyzed and found to contain only one-fourth the targeted calcium. The calcium deficit was made up by adding reagent $\mathrm{CaCO}_{3}$ along with the mercury and noble metals prior to each of the four runs. The near total dissolution of calcium indicated here is 
higher than the roughly $80 \%$ dissolution seen in previous tests, but this may be a consequence of having such a high fraction of the calcium present as the carbonate (presumably a significant fraction of the precipitated calcium plus all of the trimmed calcium were $\mathrm{CaCO}_{3}$ ).

The elemental results for rhodium can be interpreted in combination with the anion concentrations following acid addition, Table 10. While the nitrite ion concentration was high $(>1,000 \mathrm{mg} / \mathrm{kg})$, the $\mathrm{Rh}$ solubility was high, but when nitrite was destroyed, the Rh solubility became much smaller.

Table 10. Slurry anions after acid addition, $\mathrm{mg} / \mathrm{kg}$

\begin{tabular}{|l|l|l|l|l|r|c|}
\hline & Acid & Nitrite & Nitrate & Formate & Sulfate & Chloride \\
\hline SB6-12 & $100 \%$ & 5,660 & 10,000 & 34,300 & 107 & 260 \\
\hline SB6-14 & $117 \%$ & 3,500 & 13,900 & 43,600 & $<100$ & $<100$ \\
\hline SB6-15 & $133 \%$ & 1,100 & 16,000 & 47,400 & 153 & $<100$ \\
\hline SB6-13 & $150 \%$ & $<100$ & 16,900 & 49,300 & 171 & $<100$ \\
\hline
\end{tabular}

Nitrate increased with increasing acid stoichiometry for two reasons. First, more nitric acid was added in the runs with higher acid stoichiometry. Second, more nitrite had been destroyed by the end of acid addition as acid stoichiometry increased, presumably resulting in more conversion of the nitrite to nitrate. While only one-third of the nitrite in SB6-12 was destroyed by the end of acid addition, sufficient acid had been added to complete nitrite destruction by the end of the SRAT cycle.

The sulfate and chloride data are interesting. The SB6-E simulant contained about $1,000 \mathrm{mg} / \mathrm{kg}$ of sulfate ( 900 by ICP-AES sulfur, and 1100 by weighted dilution IC). Apparently less than $20 \%$ of the sulfate remained in the supernate following caustic quenching of the post-acid addition slurry. The elemental supernate data indicated about $65-70 \%$ solubility of the sulfur. Since the supernate was not caustic quenched, it appears that increasing the $\mathrm{pH}$ of the slurry by caustic addition caused much of the dissolved sulfate to precipitate. The SB6-12 chloride result represents approximately all of the chloride in the SB6-E simulant plus the $\mathrm{RuCl}_{3}$ trim. It is not clear why the chloride appears to be less soluble in the three higher acid runs.

Anion reaction extents at the end of formic acid addition are given in Table 11. Nitrite lost is the percentage of the SB6-E nitrite destroyed by the end of acid addition. Nitrate gain/loss is the change in mass of total nitrate at the end of acid addition relative to the nitrate added as SB6-E simulant, $\mathrm{Pd}$ and $\mathrm{Rh}$ nitrate solutions, $\mathrm{AgNO}_{3}$, and nitric acid. Formate lost is the percentage of the formic acid addition formate no longer present at the end of acid addition.

Table 11. Slurry anion reactions through acid addition

\begin{tabular}{|l|l|c|c|c|}
\hline & Acid & $\begin{array}{c}\text { Nitrite } \\
\text { Lost }\end{array}$ & $\begin{array}{c}\text { Nitrate } \\
\text { Gain/Loss }\end{array}$ & $\begin{array}{c}\text { Formate } \\
\text { Lost }\end{array}$ \\
\hline SB6-12 & $100 \%$ & $33 \%$ & $-5 \%$ & $15 \%$ \\
\hline SB6-14 & $117 \%$ & $58 \%$ & $8 \%$ & $8 \%$ \\
\hline SB6-15 & $133 \%$ & $86 \%$ & $14 \%$ & $8 \%$ \\
\hline SB6-13 & $150 \%$ & $>98.7 \%$ & $6 \%$ & $14 \%$ \\
\hline
\end{tabular}

The nitrate gain/loss data are significant. Normally a continuously increasing gain would be seen as a function of increasing acid stoichiometry and increasing nitrite destruction. The expected 
trend holds through the first three rows, and then reverses in the highest acid data. This reversal may be due to analytical uncertainty or it may signify that the onset of nitrate destruction associated with ammonium ion formation chemistry immediately followed nitrite destruction in SB6-13. Net nitrite-to-nitrate conversion and percent nitrite lost are plotted versus acid stoichiometry in Figure 11. Nitrite-to-nitrate conversion is calculated by dividing the moles of nitrite destroyed into the apparent gain in the number of moles of nitrate above that added to the SRAT as sludge, trim chemicals, and nitric acid.

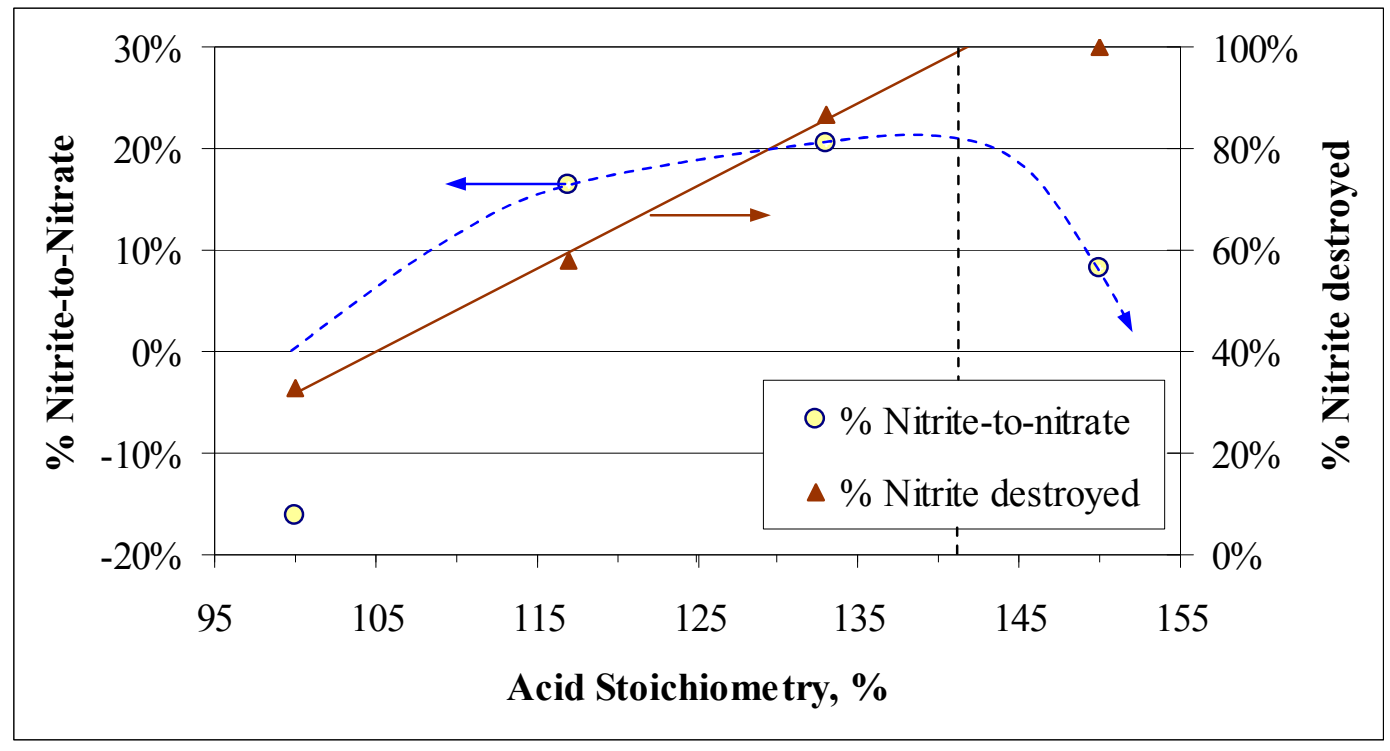

Figure 11. Graphical perspective on nitrite destruction

The curve for nitrite-to-nitrate conversion was made assuming that a percentage less than zero was not plausible for the low acid stoichiometry end, even though the analytical data indicated less nitrate was present than added (and consequently a negative $16 \%$ nitrite-to-nitrate conversion was calculated for SB6-12; this result is very sensitive to the normal analytical uncertainties of the IC given that only one-third of the nitrite has been destroyed). It appears that nitrite ion would have been destroyed more or less simultaneously with the end of acid addition at about $141 \%$ of the Koopman minimum acid stoichiometry. It is potentially possible that nitrite-tonitrate conversion would have smoothly increased up to $141 \%$ stoichiometry (if more data were available) and then started to fall as ammonium ion formation was initiated (at the expense of nitrate ions).

The formate losses indicated for SB6-12 and 13 are sufficient to cover the reduction of $\mathrm{Hg}$ and indicated reduction of $\mathrm{Mn}$ based on the solubility shown in Table 9 with some loss left over for nitrite destruction. The formate loss in SB6-13 is actually 30\% more in absolute terms than the loss in SB6-12, since 45.6\% more formate was added to 13 than to 12 . The additional loss has certainly gone to cover the extra $66 \%$ of nitrite destruction and may also have been used to cover early ammonia generation. The formate losses indicated in Table 11 for SB6-14 and 15 are not sufficient to cover the observed Mn reduction extents from Table 9 plus Hg reduction, and these results probably reflect some of the inherent uncertainty in the analyses.

SRAT product supernate was analyzed for comparison to end of acid addition supernate. The extents of dissolution of selected elements are given in Table 12 as percentages of the total element found in the supernate phase. 
Table 12. Percentages of selected elements in SRAT product supernate

\begin{tabular}{|l|l|r|r|r|r|r|r|r|r|r|}
\hline & Acid & $\mathrm{Ca}$ & $\mathrm{La}$ & $\mathrm{Mg}$ & $\mathrm{Mn}$ & $\mathrm{Ni}$ & $\mathrm{Rh}$ & $\mathrm{Ru}$ & $\mathrm{S}$ & $\mathrm{Zn}$ \\
\hline SB6-12 & $100 \%$ & 77 & 0 & 13 & 5 & 0 & 2 & $<1$ & 30 & 0 \\
\hline SB6-14 & $117 \%$ & 87 & 0 & 31 & 12 & 0 & 6 & $<1$ & 17 & 0 \\
\hline SB6-15 & $133 \%$ & 92 & 0 & 45 & 23 & 0 & 4 & $<1$ & 17 & 0 \\
\hline SB6-13 & $150 \%$ & 100 & 0 & 52 & 28 & 0 & 4 & 1 & 10 & 0 \\
\hline
\end{tabular}

The elements $\mathrm{La}, \mathrm{Ni}$, and $\mathrm{Zn}$ completely reprecipitated as the $\mathrm{pH}$ rose to seven during the long SRAT boiling period. Calcium remained extensively dissolved. $\mathrm{Mg}$ dissolution extent fell slightly, while Mn dissolution extent fell significantly. Such trends are not unexpected. Rh and $\mathrm{Ru}$ solubility went to small, nonzero numbers, which has been the general trend for these two elements during the SRAT cycle. Al and Fe had negligible solubility, while $\mathrm{K}$ and $\mathrm{Na}$ were essentially $100 \%$ soluble. Low concentrations of $\mathrm{Ba}, \mathrm{Si}$, etc. were found in the supernate, but none had solubility extents in excess of $5 \%$. The soluble $\mathrm{S}$ found in the SRAT product was only $20-50 \%$ as high as immediately following formic acid addition. It is not clear what this signifies, except potentially the formation of sulfate compounds that are only weakly soluble in neutral to alkaline solutions.

Total slurry elemental analysis, weighted dilution slurry anions, wt $\%$ total, soluble, insoluble, and calcined solids, sludge and supernate densities, and $\mathrm{pH}$ for the four SRAT and four SME products are tabulated in Appendix A. The SRAT product anions were used to determine the percent formate loss, percent nitrite loss, and the net nitrite-to-nitrate conversion for the SRAT cycle. These quantities are summarized in Table 13. Formate lost is the difference between moles of SRAT product formate and moles of formic acid added, divided by moles of formic acid added. Nitrate gain/loss is moles of SRAT product nitrate minus all sources of nitrate addition (excluding nitrite-to-nitrate conversion), divided by the sources of nitrate addition.

Table 13. SRAT cycle anion reactions

\begin{tabular}{|l|l|c|c|c|c|c|}
\hline & Acid & $\begin{array}{c}\text { Nitrite } \\
\text { Lost }\end{array}$ & $\begin{array}{c}\text { Net Nitrite- } \\
\text { to-Nitrate }\end{array}$ & $\begin{array}{c}\text { Nitrate } \\
\text { gain/loss }\end{array}$ & $\begin{array}{c}\text { Formate } \\
\text { Lost }\end{array}$ & $\begin{array}{c}\text { Formate } \\
\text { Lost, g }\end{array}$ \\
\hline SB6-12 & $100 \%$ & $>99 \%$ & $3 \%$ & $+3 \%$ & $22 \%$ & 35 \\
\hline SB6-14 & $117 \%$ & $>99 \%$ & $-10 \%$ & $-9 \%$ & $33 \%$ & 61 \\
\hline SB6-15 & $133 \%$ & $>99 \%$ & $-12 \%$ & $-9 \%$ & $38 \%$ & 78 \\
\hline SB6-13 & $150 \%$ & $>99 \%$ & $-18 \%$ & $-13 \%$ & $40 \%$ & 93 \\
\hline
\end{tabular}

Grams formate lost is given (at lab-scale) in addition to the percent, since progressively more formic acid was added as the stoichiometric factor increased. This column shows that while the percent formate loss from $133 \%$ to $150 \%$ acid only increased by $5 \%,(40 \%-38 \%) / 38 \%$, the actual formate loss increased by $19 \%,(93-78) / 78$. Nitrate gain/loss is given in addition to the nitrite-tonitrate conversion, since the negative nitrite-to-nitrate conversions lack physical significance. The three higher acid runs had net nitrate losses (negative gains) relative to the feed, trim, and nitric acid nitrate masses (the inputs of nitrate to the system).

The SRAT losses all have uncertainty due to the calculation of the SRAT product mass. The SRAT product mass was calculated using the weighed SME product mass plus the SME frit slurry addition masses, dewatering masses, sample masses, etc. and allowing for some losses to the off-gas during the SME cycle. 
SRNL-STI-2010-00173

Revision 0

The SME cycle nitrate and formate losses are given in Table 14.

Table 14. SME cycle anion losses

\begin{tabular}{|l|l|r|c|}
\hline & Acid & $\begin{array}{c}\text { Nitrate } \\
\text { Lost }\end{array}$ & $\begin{array}{c}\text { Formate } \\
\text { Lost }\end{array}$ \\
\hline SB6-12 & $100 \%$ & $12 \%$ & $8 \%$ \\
\hline SB6-14 & $117 \%$ & $2 \%$ & $2 \%$ \\
\hline SB6-15 & $133 \%$ & $6 \%$ & $6 \%$ \\
\hline SB6-13 & $150 \%$ & $15 \%$ & $11 \%$ \\
\hline
\end{tabular}

The molar ratio of formate to nitrate in the SME was roughly four to one, and the formate loss associated with converting one nitrate to ammonia is four moles of formate, so it is perhaps not surprising that the percent nitrate loss and formate loss are comparable in the three higher acid stoichiometry runs where significant ammonia formation was observed. The relatively high nitrate loss in SB6-12 suggests that perhaps the SRAT loss was underestimated or that the sample result was somewhat low. The SME cycle anion losses are also subject to the uncertainty in the estimation of the SRAT product mass. Increasing the estimated SRAT product mass moves loss from the SME cycle to the SRAT cycle, while decreasing the estimated SRAT product mass has the opposite effect.

Rheological data were not obtained on the qualification simulant SRAT and SME products, since the analogous radioactive slurries will not be processed in DWPF. Rheological data will be obtained as part of the Phase III simulant flowsheet study based on the latest estimates of the composition of Tank 40 following transfer of SB6 from Tank 51 to Tank 40.

\subsection{Off-gas Data}

Gas chromatography was used to analyze the composition of the off-gas downstream of the chilled condenser (FAVC). Because of the length of the SRAT cycle and the presence of a SME cycle, several different time axes were created to facilitate data comparisons. SRAT cycle hydrogen data are given in Figure 12. 


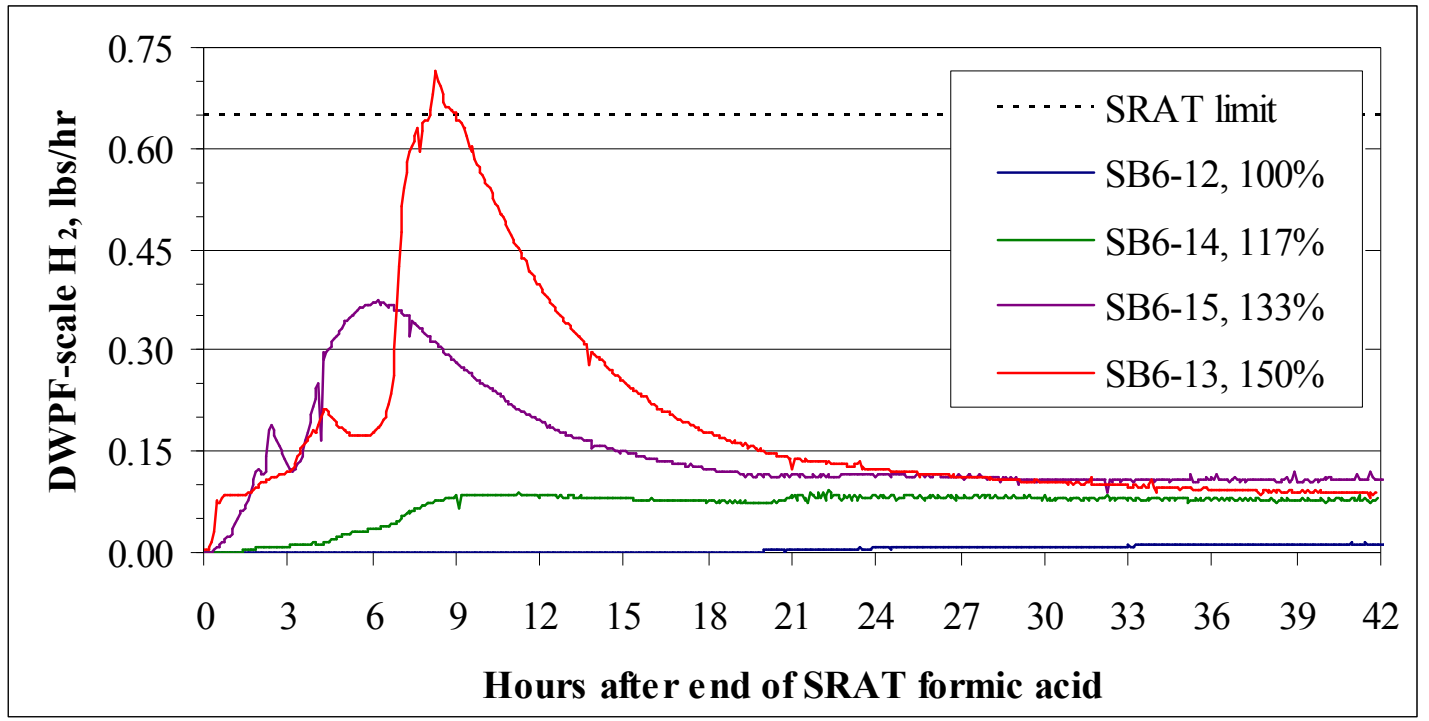

Figure 12. SRAT cycle hydrogen generation

Note that the time axis covers 42 hours versus the 16-18 hours typical of many previous runs. The peaks above would appear quite broad when plotted versus a 16 hour range, and they integrate to significant total mass of hydrogen except in SB6-12. Rh-catalyzed hydrogen generation usually occurs shortly after nitrite destruction. In SB6-13, hydrogen rose to about 0.1 $\mathrm{lb} / \mathrm{hr}$ shortly after formic acid addition. This is presumably the period of peak Rh catalytic activity. There was a first peak in generation around the four hour mark when the SRAT went to reflux (fresh infusion of nitrite ion), and a second peak at about nine hours which would appear to be the peak dominated by Ru catalysis. This second peak reached $110 \%$ of the DWPF SRAT limit of $0.65 \mathrm{lbs} / \mathrm{hr}$.

SB6-15 hydrogen initially rose slightly later than SB6-13 due to the reduced acid and rose to a peak at about 2.5 hours presumably dominated by Rh catalysis. It then rose to a second peak at about 5.5 hours at slightly over half the DWPF limit. It is not clear what conditions led to this second peak coming sooner than that in SB6-13. It may be related to the ammonium formation in SB6-15, which released $\mathrm{N}_{2} \mathrm{O}$ during this period, and in advance of the $\mathrm{N}_{2} \mathrm{O}$ and major $\mathrm{H}_{2}$ production periods of SB6-13 and 14. Both phenomena may also be related to the unexplained rapid loss of mercury from the bulk slurry in SB6-15 compared to SB6-13 and 14.

SB6-14 (117\%) didn't have any obvious peaks in hydrogen generation rate. The generation rate increased slowly following nitrite destruction to $0.075-0.085 \mathrm{lbs} / \mathrm{hr}$ and held in that range for over 30 hours. SB6-12 (100\% acid case) reached a generation rate of $0.004 \mathrm{lb} / \mathrm{hr}$ at 20 hours after the end of formic acid addition. In many past SRAT simulations the SRAT cycle would have ended before this hydrogen was seen. This result is consistent with $100 \%$ of the Koopman minimum acid equation being fairly close to the minimum acid for nitrite destruction for SB6-E simulant trimmed as in these tests.

Processed hydrogen data from the SME cycle are given in Figure 13. Following completion of reflux in the SRAT, the slurry was cooled down for sampling. Then frit, formic acid, and water were added which further cooled the slurry. The purge flow rates were adjusted, and the slurry was brought back to boiling. Because of the additional formic acid and concentration changes in 
the system from the frit slurry addition, the hydrogen generation rates vary from those at the end of the SRAT reflux period.

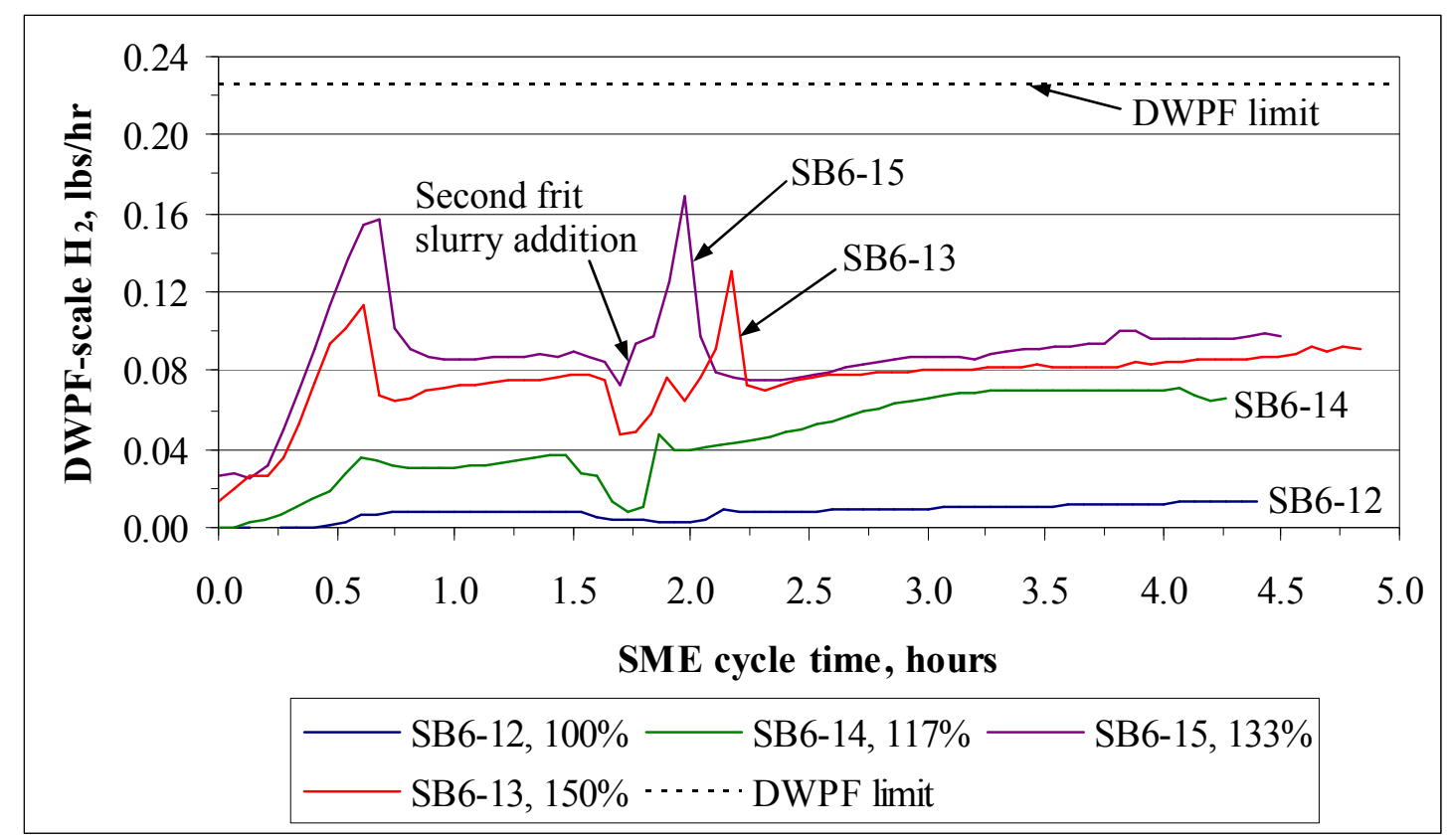

Figure 13. SME cycle hydrogen generation rates

SB6-15 (133\%) was at a higher hydrogen generation rate than SB6-13 $(150 \%)$ at the end of the SRAT, and that relative position was maintained through the SME cycle. Two surges came in both of these runs as the SME slurry was brought to boiling after each of the two frit slurry additions. These surges were at 1.5 to 2 times the steady generation rates. SB6-15 reached $75 \%$ of the SME limit during one of these surges. It is not clear whether or not the surges are prototypical of DWPF frit slurry additions.

Hydrogen generation rates crept up in all four runs as the SME was concentrated to the target solids loading. Final SME dewatering increased the concentrations of the noble metals and remaining formic acid, i.e. expected kinetic effects qualitatively explain the gradual increases seen from 2.5 to 4.5 hours into the SME cycle. The SME cycle was fairly short, because there were no canister decon water additions. The results, however, are believed to be bounding for hydrogen generation, since the additional formic acid in the frit slurry was introduced sooner into the SME slurry than if there had been canister decon water additions.

SRAT cycle carbon dioxide data were aligned such that the time axis approximately represents the moles acid added to the SRAT. The start of formic acid was chosen from SB6-13 as the baseline zero time. This was close to the equivalent time in SB6-14 and 15 with respect to moles acid. The SB6-12 data had to be shifted about fifteen minutes to align it to an equivalent moles acid. An equivalent moles acid alignment permits evaluating the common and different features in the $\mathrm{CO}_{2}$ off-gas profile as a function of acid added more readily than using the end of formic acid as the zero time. Aligned data are given in Figure 14. 


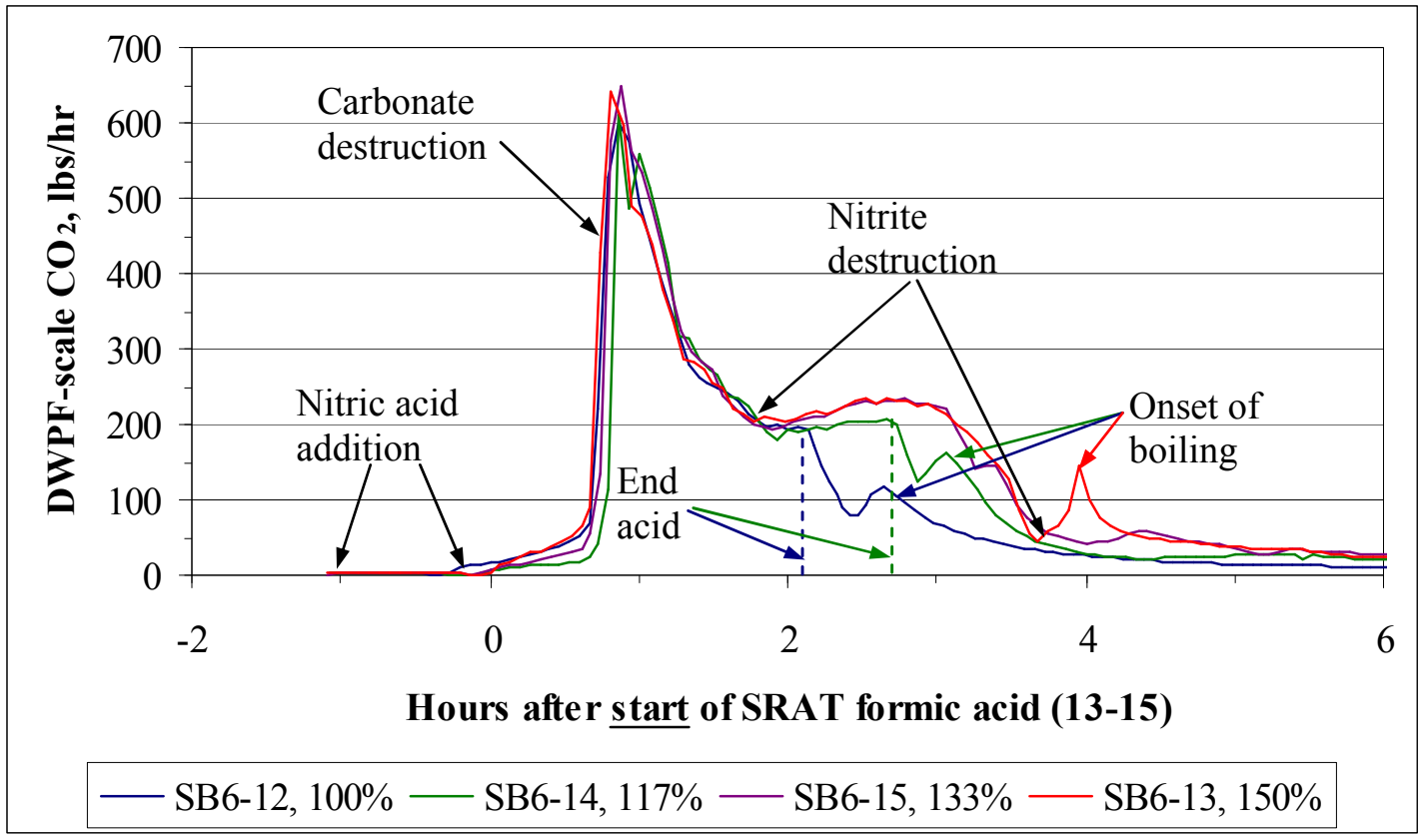

Figure 14. Carbon dioxide during acid addition and dewatering

Carbonate destruction, centered at about one hour into formic acid addition, was essentially independent of the acid stoichiometry as expected. Variations in the $\mathrm{CO}_{2}$ from nitrite destruction were observed at lower acid stoichiometry as the formic acid addition ended at 2.1 hours in SB612 and at 2.7 hours in SB6-14. The similarity in the profiles from -1 to +2 hours is also a semiquantitative confirmation that the four SRAT vessels were batched nearly identically as planned. Small peaks (one per curve) between 2.4 and 4.2 hours indicate the onset of boiling which displaces accumulated $\mathrm{CO}_{2}$ in the equipment. No specific feature for $\mathrm{CO}_{2}$ from mercury reduction was identified in spite of the high initial mercury concentration.

The $\mathrm{CO}_{2}$ generation following formic acid addition through reflux is shown in Figure 15. 


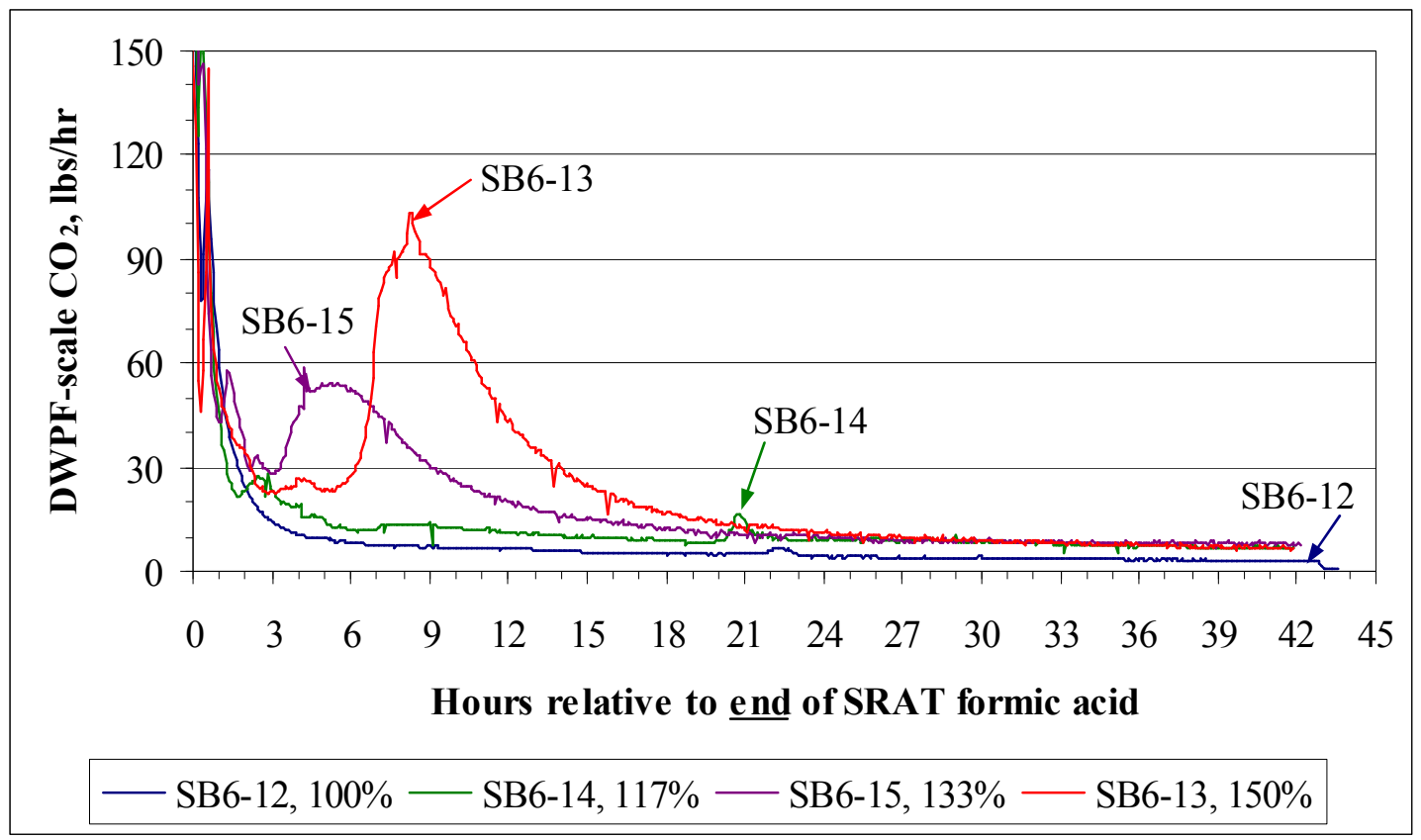

Figure 15. Carbon dioxide generation following formic acid addition

The two large peaks in $\mathrm{CO}_{2}$ production in SB6-13 and 15 align with the two main hydrogen generation rate peaks in Figure 12. There is an unidentified peak in $\mathrm{SB} 6-14 \mathrm{CO}_{2}$ generation rate at 21 hours after formic acid addition that is quite apparent when enlarged, not associated with a corresponding hydrogen peak, and that lasted over an hour.

Formic acid can be destroyed by oxidation and decomposition (as well as other reactions). The two reactions are given by:

$$
\begin{aligned}
& \mathrm{HCOOH}+1 / 2 \mathrm{O}_{2} \rightarrow \mathrm{CO}_{2}+\mathrm{H}_{2} \mathrm{O} \\
& \mathrm{HCOOH} \rightarrow \mathrm{CO}_{2}+\mathrm{H}_{2}
\end{aligned}
$$

Forming a group containing twice the $\mathrm{O}_{2}$ flowrate plus the $\mathrm{CO}_{2}$ flowrate should give a constant flowrate if the only reaction impacting formic acid is oxidation. Similarly, forming a group containing the $\mathrm{CO}_{2}$ flowrate minus the $\mathrm{H}_{2}$ flowrate should give a constant (zero) flowrate if the only reaction impacting formic acid is decomposition. Forming the flowrate group $\left(2 * \mathrm{O}_{2}+\mathrm{CO}_{2}\right.$ $\mathrm{H}_{2}$ ) should give a constant flowrate if oxidation and decomposition are the only two reactions impacting formic acid. Figure 16 shows this group for the three SRAT cycles that produced significant ammonia. The actual plotted points are moving averages of five points centered at the time shown, two from just before the time, two from just after the time, and one from the same time. Averaging was done to smooth the curves, which otherwise are fairly noisy due to the accumulation of small random fluctuations in all three quantities in the sum. 


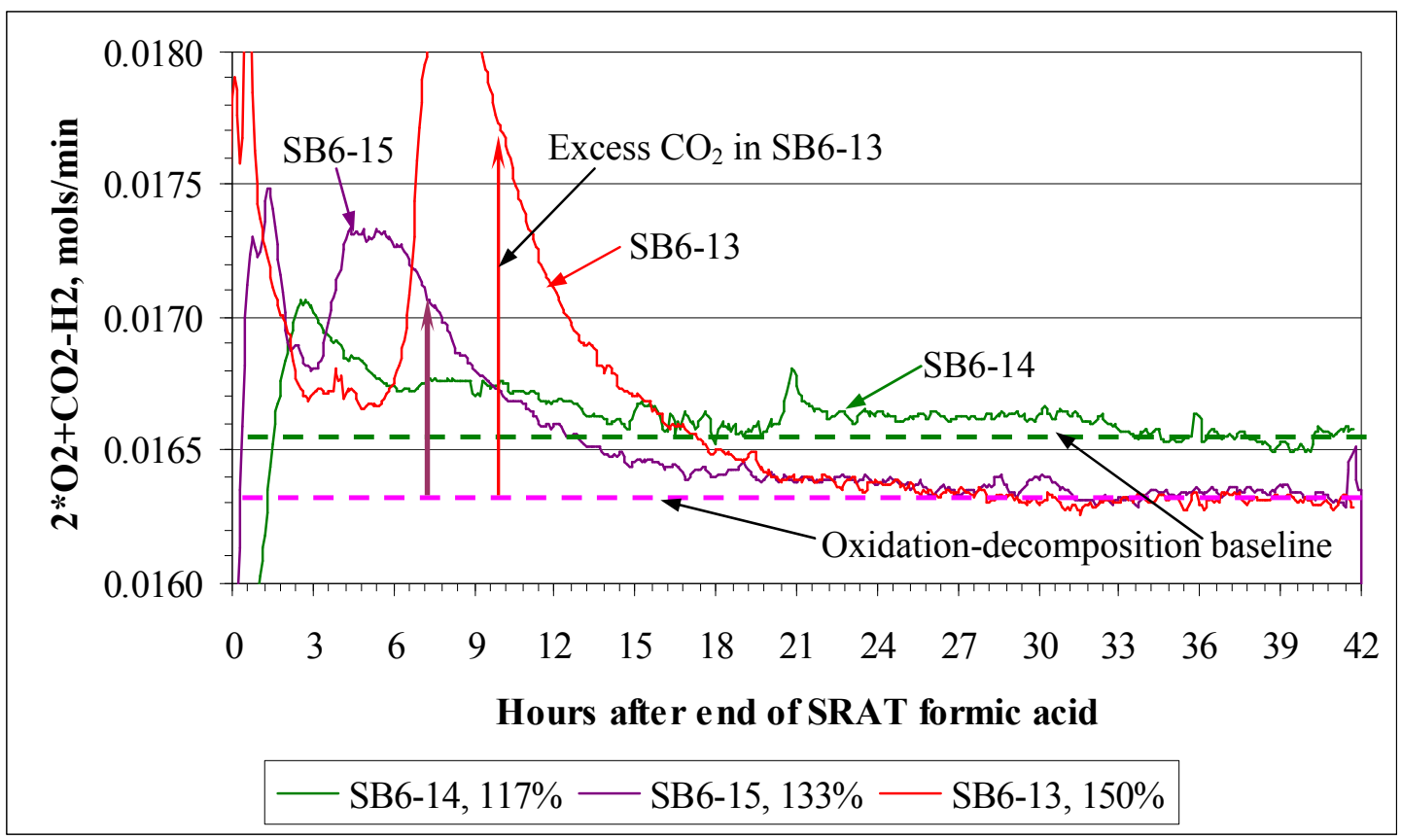

Figure 16. Net flowrate of $\left(2 * \mathrm{O}_{2}+\mathrm{CO}_{2}-\mathrm{H}_{2}\right)$ during boiling

Baseline flow rates are given assuming that extra reactions have gone to zero by the end of the SRAT reflux period. SB6-13 and SB6-15 data were taken on the same GC from lab-scale SRAT assemblies using the same MKS air and He flow controllers, which may explain why they are superimposed from 24 to 42 hours, while there is a small 1.3\% offset in the sum relative to SB614 (so two baselines are shown). In spite of correcting for oxidation and decomposition reactions of formic acid, there are significant deviations in the flow rate group around the time of hydrogen generation in SB6-13 and 15 (3-18 hour period after formic acid addition). This period is past the time for nitrite destruction (based on $\mathrm{N}_{2} \mathrm{O}$ data below and nitrite sample results) and probably also for $\mathrm{Mn}$ reduction in these two higher acid runs. The period for maximum catalytic activity for hydrogen generation may correspond to the period of maximum catalytic activity for ammonia generation based on the timing of the unexplained (excess) $\mathrm{CO}_{2}$ formation.

The relatively early period from near the end of acid addition out to +18 hours also corresponds to the presence of the most excess acid in the SRAT, when a reaction that converts four formates to $\mathrm{CO}_{2}$ while consuming five acidic protons might be kinetically favored compared to later in the SRAT when $\mathrm{pH}$ has risen toward neutral conditions. This hypothesized period for ammonia formation is also consistent with ammonia formation starting during acid addition during SB6-13 as suggested by anion data, although the presentation in Figure 16 can not be extended into the period around nitrite destruction, because $\mathrm{CO}_{2}$ associated with nitrite destruction overwhelms other deviations from the oxidation and decomposition baseline during this testing. This hypothesis is also consistent with the Phase II ammonium ion data where more SRAT ammonium was found in the SRAT after 24 hours of boiling at $150 \%$ acid than was found after 42 hours of boiling.

$\mathrm{CO}_{2}$ production was seen during the SME cycle, and the data, converted to equivalent DWPFscale $\mathrm{lbs} / \mathrm{hr}$, are given in Figure 17. 


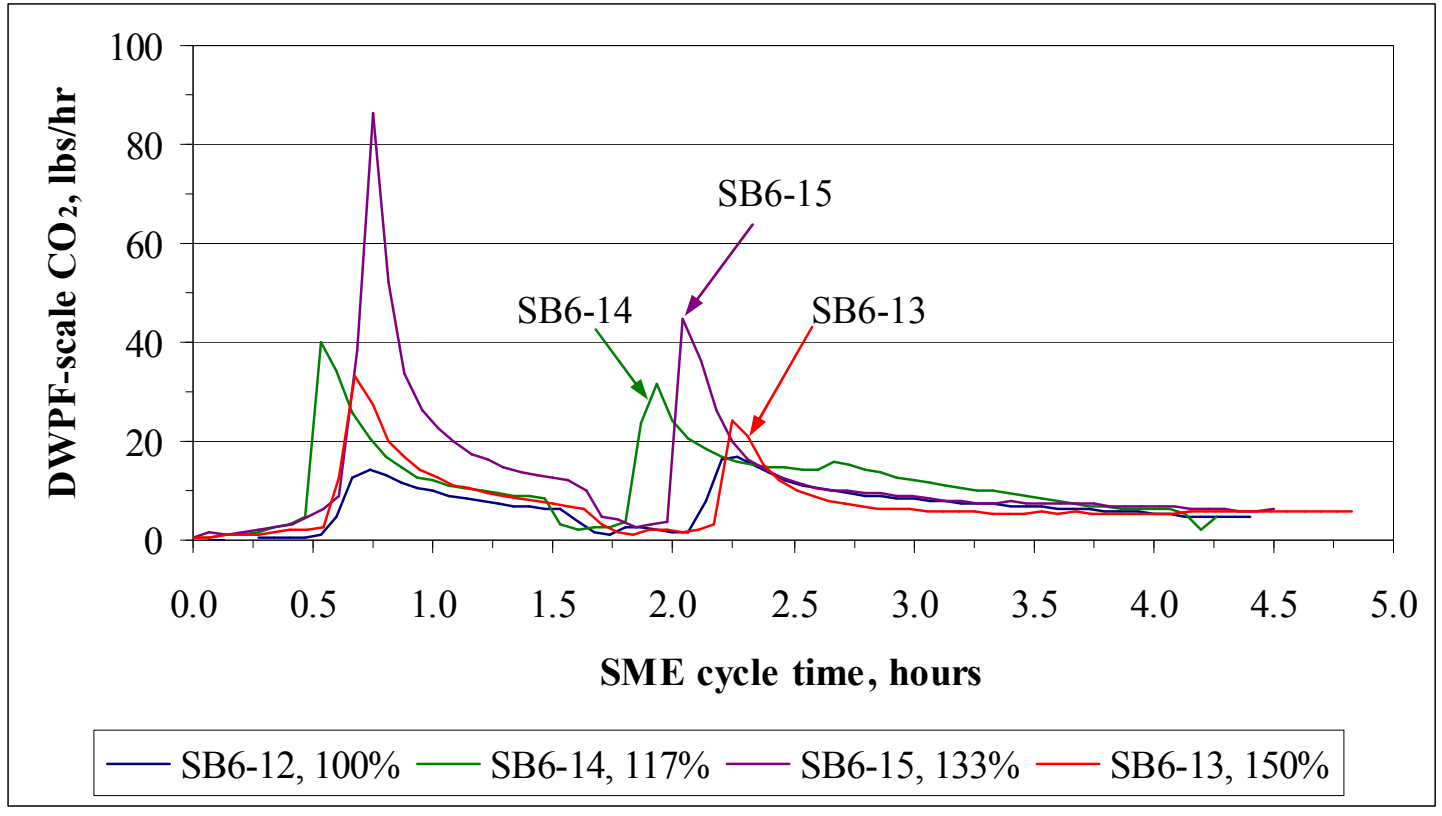

Figure 17. SME cycle carbon dioxide generation

The SME cycle carbon dioxide data appeared to be fairly typical of past SME simulations.

The $\mathrm{N}_{2} \mathrm{O}$ generation during the early SRAT cycle is compared in Figure 18 using the same time scale as Figure 14. Dashed vertical lines mark the ends of formic acid addition in the four runs. The lines are colored coded to the respective curve.

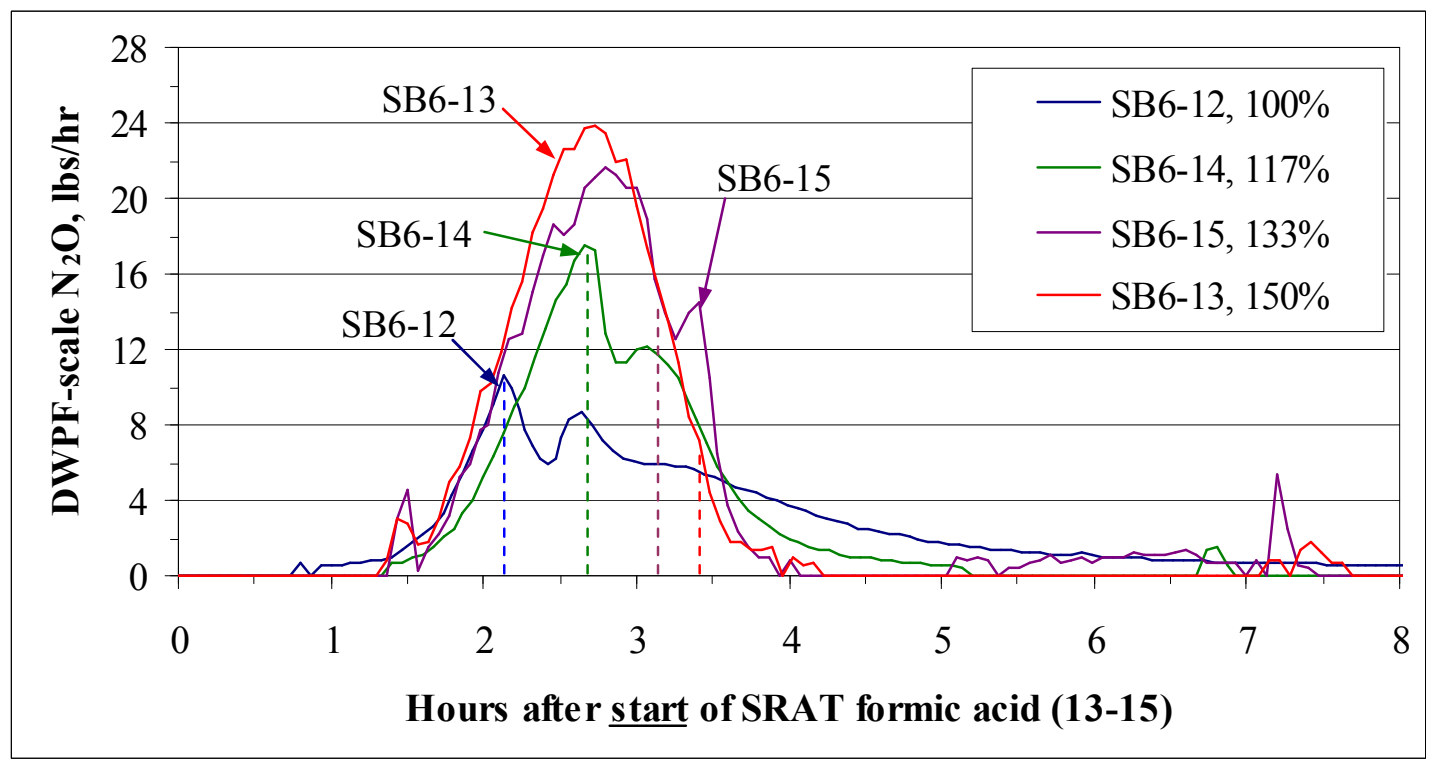

Figure 18. Nitrous oxide during SRAT acid addition and dewatering

At $100 \%$ and $117 \%$ stoichiometry, the end of acid addition led to a rapid drop in the rate of $\mathrm{N}_{2} \mathrm{O}$ generation. Comparison with the $133 \%$ and $150 \%$ data suggest that nitrite was less than half 
destroyed in the two low acid runs when acid addition ended based on peak height, but anion samples indicated slightly over $50 \%$ destruction at the end of acid addition in the $117 \%$ run. The implication is that lower acid preferentially favored other by-products of nitrite destruction than $\mathrm{N}_{2} \mathrm{O}$. The formation of $\mathrm{N}_{2} \mathrm{O}$ during reflux was discussed with ammonium ion formation in section 3.2 with one exception. A small quantity of $\mathrm{N}_{2} \mathrm{O}$ was also seen in the SB6-12 SME cycle, but not in the other three runs.

The amount of $\mathrm{N}_{2} \mathrm{O}$ produced in the SB6 simulant tests was low compared to earlier sludge batches such as SB4. The SB4 qualification simulant block of four SRAT simulations had peak $\mathrm{N}_{2} \mathrm{O}$ generation rates of $87-103 \mathrm{lb} / \mathrm{hr}$, versus the $10-24 \mathrm{lb} / \mathrm{hr}$ range here. ${ }^{13}$ SB5 qualification simulant SRAT simulations had peaks in $\mathrm{N}_{2} \mathrm{O}$ of $45-55 \mathrm{lbs} / \mathrm{hr} .{ }^{14}$ The difference is attributed to mercury, which has been shown to catalyze the conversion of nitrite to $\mathrm{NO}$ at the expense of $\mathrm{N}_{2} \mathrm{O}$ formation. ${ }^{15}$ Mercury was increased from 2.58 to $3.9 \mathrm{wt} \%$ between SB4 and SB6.

The GC data were combined with the He internal standard flowrate and integrated over the SRAT cycle to produce total masses. Semi-quantitative estimates for $\mathrm{NO}_{2}$ and $\mathrm{NO}$ were prepared using oxygen consumption as a basis for $\mathrm{NO}_{2}$, and the historical ratio of $\mathrm{NO} / \mathrm{He}$ calibration factors to integrate the relatively small NO peaks.

Table 15. GC relative masses of SRAT off-gas species in grams

\begin{tabular}{|l|c|c|c|c|c|c|}
\hline & Acid & $\mathrm{H}_{2}$ & $\mathrm{CO}_{2}$ & $\mathrm{~N}_{2} \mathrm{O}$ & $\mathrm{NO}_{2}$ & $\mathrm{NO}$ \\
\hline SB6-12 & $100 \%$ & 0.013 & 54.6 & 1.41 & 21 & 0.6 \\
\hline SB6-14 & $117 \%$ & 0.189 & 71.8 & 1.52 & 23 & 1.3 \\
\hline SB6-15 & $133 \%$ & 0.413 & 98.5 & 1.96 & 25 & 1.6 \\
\hline SB6-13 & $150 \%$ & 0.526 & 116.3 & 2.05 & 25 & 1.9 \\
\hline
\end{tabular}

There are some weak trends in the oxides of nitrogen data, such as more $\mathrm{N}_{2} \mathrm{O}, \mathrm{NO}_{2}$, and $\mathrm{NO}$ as stoichiometry goes up. This trend generally signifies increasing catalytic attack on nitrite by mercury and noble metals as the quantity of formic acid added increases. In the absence of ammonia formation, nitrite-to-nitrate conversion would typically drop from around $20 \%$ to $10 \%$ for such an increase in stoichiometry as a consequence of the increase in the fraction of nitrite converted to gaseous oxides of nitrogen. In these runs, however, the drop in nitrite-to-nitrate conversion was from $3 \%$ to $-18 \%$.

The range in total mass of carbon dioxide generated in the SRAT did not match historical trends. More than twice as much $\mathrm{CO}_{2}$ was produced at $150 \%$ acid compared to $100 \%$ acid. An increase in $\mathrm{CO}_{2}$ with increasing stoichiometry was expected, even one somewhat larger than the 1.5 increase in acid stoichiometry. An increase by a factor of 2.13 , however, was not expected. The likely explanation is the additional $\mathrm{CO}_{2}$ produced during ammonia formation.

Hydrogen mass data followed previous trends. SB6-12 was very close to minimum acid, since the GC data indicated nitrite destruction took until about eight hours after formic acid addition. Detectable hydrogen did not appear until 20 hours after the end of formic acid addition which would have been after the end of the SRAT cycle in lower mercury concentration tests.

The cation, anion and GC data were combined to prepare a molar balance for nitrogen (excluding $\mathrm{N}_{2}$ gas). Table 16 summarizes the nitrogen inputs to the SRAT. The nitrite and nitrate include analytical uncertainties of about $10 \%$ from the IC analysis, or about \pm 0.11 moles in the sum. 
Table 16. Nitrogen input species to SRAT, as moles $\mathbf{N}$

\begin{tabular}{|l|c|c|c|c|c|c|}
\hline & Acid & $\begin{array}{c}\text { Sludge } \\
\text { Nitrate }\end{array}$ & $\begin{array}{c}\text { Trim } \\
\text { Nitrate }\end{array}$ & $\begin{array}{c}\text { Sludge } \\
\text { Nitrite }\end{array}$ & $\begin{array}{c}\text { Nitric } \\
\text { Acid }\end{array}$ & Sum In \\
\hline SB6-12 & $100 \%$ & 0.309 & 0.004 & 0.715 & 0.357 & 1.385 \\
\hline SB6-14 & $117 \%$ & 0.309 & 0.004 & 0.715 & 0.506 & 1.534 \\
\hline SB6-15 & $133 \%$ & 0.309 & 0.004 & 0.715 & 0.591 & 1.619 \\
\hline SB6-13 & $150 \%$ & 0.309 & 0.004 & 0.715 & 0.731 & 1.759 \\
\hline
\end{tabular}

Table 17 contains terms for measured nitrogen species leaving the SRAT. Nitrate plus nitrite includes nitrate in the SRAT product along with nitrite and nitrate in the SRAT dewater condensate. Ammonium includes ammonium ion in both the SRAT product and FAVC condensate (except SB6-12, where the SRAT product was not checked for ammonium). These two terms and the off-gas $\mathrm{N}_{2} \mathrm{O}$ have analytical uncertainties of order $10 \%$ or \pm 0.1 moles. The $\mathrm{NO}+\mathrm{NO}_{2}$ term has uncertainty estimated to be of order $20 \%$ or \pm 0.06 moles. A small amount of nitrate in the FAVC was not quantified, but could easily be of order 0.1 mole.

Table 17. Nitrogen species leaving SRAT, as moles $\mathbf{N}$

\begin{tabular}{|l|c|c|c|c|c|c|}
\hline & Acid & $\begin{array}{c}\text { Nitrate }+ \\
\text { nitrate }\end{array}$ & Ammonium & $\mathrm{N}_{2} \mathrm{O}$ & $\mathrm{NO}_{2}+\mathrm{NO}$ & Sum Out \\
\hline SB6-12 & $100 \%$ & 0.764 & 0.008 & 0.064 & 0.486 & 1.323 \\
\hline SB6-14 & $117 \%$ & 0.833 & 0.065 & 0.069 & 0.549 & 1.515 \\
\hline SB6-15 & $133 \%$ & 0.843 & 0.102 & 0.089 & 0.612 & 1.646 \\
\hline SB6-13 & $150 \%$ & 0.926 & 0.161 & 0.093 & 0.616 & 1.796 \\
\hline
\end{tabular}

The inputs and outputs are combined in Table 18. Uncertainty in the inputs and outputs are cumulative, or of order 0.37 moles ammonium per run, which tends to overwhelm the nitrogen material balance closure estimation. Delta is ((moles in - moles out $) /($ moles in $))^{*} 100 \%$.

Table 18. Nitrogen balance

\begin{tabular}{|l|c|c|c|c|}
\hline & Acid & Moles In & Moles Out & Delta \\
\hline SB6-12 & $100 \%$ & 1.385 & 1.323 & $-4.5 \%$ \\
\hline SB6-14 & $117 \%$ & 1.534 & 1.515 & $-1.2 \%$ \\
\hline SB6-15 & $133 \%$ & 1.619 & 1.646 & $+1.7 \%$ \\
\hline SB6-13 & $150 \%$ & 1.759 & 1.796 & $+2.1 \%$ \\
\hline
\end{tabular}

Except for the inherent analytical uncertainties, the nitrogen material balances closed fairly well (inputs indistinguishable from outputs). Four small errors, two positive and two negative, were calculated ignoring the uncertainty. Because of the uncertainty, however, it is possible that ammonia moles equal to or exceeding those found in the SRAT product and FAVC condensate could have escaped via the off-gas stream. The lab-scale FAVC was essentially operating as a wetted-wall absorption column for ammonia leaving the SRAT in the off-gas. This is not its designed function. Lab-scale ammonia scrubbers are being installed on the two 4-L SRAT rigs for improved quantification of ammonia venting from the SRAT slurry. The scrubbing acid will be checked for accumulated ammonium following the SRAT. The FAVC will continue to serve 
as a wetted-wall absorption column downstream of the scrubber, and it will be checked to determine if much ammonia made it past the scrubber.

The 0.171 moles ammonium ion collected in SB6-13 correspond to a loss of $30.8 \mathrm{~g}$ of formate out of $231.4 \mathrm{~g}$ formate added as formic acid. That is, the quantified ammonium formation accounted for a $13.3 \%$ formate loss, while the SRAT overall had a $40 \%$ formate loss (a third of the formate loss was due to ammonia formation).

SME cycles consisted of two frit slurry additions and related dewatering. SME condensates from the three higher acid runs were checked for ammonium ion. It was found that ammonium ion equivalent to $30-40 \%$ of the ammonium ion in the SB6-13 and 15 SRAT products was in the two SME cycle condensates. For SB6-14, the equivalent of $17 \%$ of the ammonium ion in the SRAT product was found in the first frit addition dewatering condensate (the larger second frit addition/final SME dewatering condensate had been used and could not be tested - in both SB613 and 15, the second frit/final dewatering had more ammonium ion mass than the first frit dewatering condensate, so it is quite possible that over $40 \%$ of the ammonium ion in the SB6-14 SRAT product went to the SME cycle condensates).

The SME cycle condensates were cooled to about $25^{\circ} \mathrm{C}$ in the SME condenser, and the quantities above represent the ammonia that was absorbed into the condensate. The SME condenser runs much warmer than the FAVC, where much of the ammonium ion was collected during the SRAT cycle. Additional ammonia vapor may have passed through the SME condenser. Very little FAVC condensate was collected during the SME cycle. Fresh ammonium ion may have been produced in the SME slurry as well. The Phase III flowsheet studies will include canister decon dewatering steps as well as an ammonia scrubber, so the behavior of ammonium ion/ammonia in the SME cycle should be better understood following those tests.

\subsection{Conclusions}

Qualification simulant testing was completed to determine appropriate processing conditions and assumptions for the SB6 Shielded Cells demonstration of the DWPF flowsheet using the actual Tank 51 washed SB6 qualification sample. It was found that an acid addition window of 105$139 \%$ of the DWPF acid equation (100-133\% of the Koopman minimum acid equation) gave acceptable SRAT and SME results for nitrite destruction and hydrogen generation.

Two processing issues were noted. The first issue was inadequate mercury suspension in the SRAT slurry that impacted mercury stripping leading to higher SRAT product mercury concentrations than targeted ( $>0.45 \mathrm{wt} \%$ in the total solids). Associated with this issue was a general difficulty in quantifying the mass of mercury in the SRAT vessel as a function of time. About ten times more mercury was found after drying the 150\% acid SME product to powder than was indicated by the slurry sample results. Significantly more mercury was also found in the $133 \%$ acid SME product sample than was found during the SRAT cycle sampling. It appears that mercury is being segregated from the bulk slurry in the SRAT vessel and is not being resuspended by the agitators.

The second processing issue was significant ammonium ion formation as the acid stoichiometry was increased due to the high noble metal-high mercury feed conditions. Ammonium ion was found partitioned between the SRAT product slurry and the condensate from the lab-scale off-gas chiller downstream of the SRAT condenser. The ammonium ion was produced from nitrate ion 
by formic acid. Formate losses increased with increasing acid stoichiometry reaching $40 \%$ at a stoichiometry that just exceeded the SRAT hydrogen limit by $10 \%$. About a third of the formate loss at higher acid stoichiometries appeared to be due to ammonia formation. The full extent of ammonia formation was not determined in these tests, since uncondensed ammonia vapor was not quantified. Nitrate losses during ammonia formation led to nitrite-to-nitrate conversion values that were negative in three of the four tests. The negative results are an artifact of the calculation which was based on negligible SRAT nitrate losses. The sample data after acid addition indicated that some of the nitrite was converted to nitrate, so the amount of nitrate destroyed included nitrite converted to nitrate plus some of the added nitrate from the sludge and nitric acid.

Hydrogen generation occurred continuously after acid addition in three of the four tests. The three runs at $117-150 \%$ stoichiometry were all still producing around $0.1 \mathrm{lb}$ hydrogen $/ \mathrm{hr}$ at DWPF scale after 42 hours of boiling in the SRAT. The $150 \%$ acid run reached $110 \%$ of the DWPF SRAT limit of $0.65 \mathrm{lb} \mathrm{H}_{2} / \mathrm{hr}$, and the $133 \%$ acid run reached $75 \%$ of the DWPF SME limit of $0.225 \mathrm{lb} \mathrm{H}_{2} / \mathrm{hr}$. Conversely, nitrous oxide generation was subdued compared to earlier sludge batches, staying below $25 \mathrm{lb} / \mathrm{hr}$ in all four tests or about a fourth as much as in comparable SB4 testing.

\subsection{Recommendations and Future Work}

A separate memo was prepared to provide processing recommendations for the SRNL Shielded Cells qualification SRAT/SME simulation. ${ }^{16}$ The memo recommended a $115 \%$ acid stoichiometry given the high level of catalytic activity found in the SB6-E simulant system.

Higher mixing speeds will be used to determine their impact on mercury suspension during the SB6 Phase III flowsheet testing. Sampling of the SRAT bulk slurry for mercury will be continued into this series of tests.

An ammonia scrubber has been developed and installed between the SRAT condenser and the chilled water condenser. The goal of the scrubber is to help quantify ammonia generation and the release of ammonia to the off-gas. The scrubber is not a lab-scale prototype of the DWPF SRAT ammonia scrubber, since its purpose is not to improve understanding of any particular issues with the DWPF scrubber.

The potential presence of significant ammonium ion in the SME slurry (as opposed to dissolved ammonia gas) could have impacts on the glass properties and redox state. It is recommended that a technical study investigate the potential impacts of ammonium ion on DWPF melter glass. 
SRNL-STI-2010-00173

Revision 0

\subsection{References}

${ }^{1}$ Bricker, J. M., Sludge Batch 6 Flowsheet Studies, HLW-DWPF-TTR-2008-0043, Rev. 0, Savannah River Site, Aiken, SC 29808 (2008).

${ }^{2}$ Lambert, D. P., Sludge Batch 6 Simulant Flowsheet Studies, SRNL-RP-2008-01341, Rev. 0, SRNL, Aiken, SC 29808 (2009).

${ }^{3}$ Pareizs, J. M., C. J. Bannochie, et al., Sludge Washing and Demonstration of the DWPF Flowsheet in the SRNL Shielded Cells for Sludge Batch 5 Qualification, SRNS-STI-2008-00111, Rev. 0, Savannah River Site, Aiken, SC, 29808 (November 2008).

${ }^{4}$ Koopman, D. C., J. M. Pareizs, et al., Sludge Batch 4 Follow-up Qualification Studies to Evaluate Hydrogen Generation, WSRC-TR-2007-00212, Rev. 0, Savannah River Site, Aiken, SC, 29808 (June 2007).

${ }^{5}$ Pareizs, J. M., D. C. Koopman, et al., Sludge Batch 3 Qualification in the SRTC Shielded Cells, WSRC-TR-2004-00050, Savannah River Site, Aiken, SC, 29808 (May 2004).

${ }^{6}$ Fellinger, T. L., J. M. Pareizs, et al., Confirmation Run of the DWPF SRAT Cycle Using the Sludge-only Flowsheet with Tank 40 Radioactive Sludge and Frit 200 in the Shielded Cells Facility, WSRC-TR-2002-00076, Rev. 0, Savannah River Site, Aiken, SC, 29808 (April 2002).

${ }^{7}$ Newell, J. D., Simulant Development for Sludge Batch 6, SRNL-STI-2010-00219, SRNL, Aiken, SC, 29808 (May 2010).

${ }^{8}$ Bannochie, C. J., J. M. Pareizs, and D. R. Click, Tank 51 SB6 Qualification SRAT Receipt Characterization, SRNL-L3100-2010-00027, Rev. 0, SRNL, Aiken, SC, 29808 (February 2010).

${ }^{9}$ Koopman, D. C., A. I. Fernandez, B. R. Pickenheim, Preliminary Evaluations of Two Proposed Stoichiometric Acid Equations, Rev. 0, SRNL-L3100-2009-00146, SRNL, Aiken, SC 29808 (June 2009).

${ }^{10}$ Marek, J. C. and R. E. Eibling, Calculational Algorithms for Nitric Acid Sludge Adjustment, SRTC-PTD-92-0050, Savannah River Site, Aiken, SC, 29808 (September 1992).

${ }^{11}$ Jantzen, C. M. and M. E. Stone, Role of Manganese Reduction/Oxidation (RedOx) on Foaming and Melt Rate in High Level Waste Melters, WSRC-STI-2006-00066, Savannah River Site, Aiken, SC, 29808 (March 2007).

${ }^{12}$ Koopman, D. C. and D. R. Best, Sludge Batch 6 Phase II Flowsheet Simulations, SRNL-STI2010-00041, Savannah River Site, Aiken, SC, 29808 (February 2010).

${ }^{13}$ Koopman, D. C., D. P. Lambert, D. R. Best, and M. J. Barnes, DWPF Simulant CPC Testing in Support of Sludge Batch 4 Qualification, WSRC-STI-2006-00062, Savannah River Site, Aiken, SC, 29808 (October 2006).

${ }^{14}$ Lambert, D. P., et al., Sludge Batch 5 Simulant Flowsheet Studies, SRNS-STI-2008-00024, Savannah River Site, Aiken, SC, 29808 (October 2008).

${ }^{15}$ Koopman, D. C., DWPF Catalytic Hydrogen Generation Program - Review of Current Status, SRNL-STI-2009-00214, SRNL, Aiken, SC, 29808 (July 2009).

${ }^{16}$ Koopman, D. C., Recommendations for SB6 Qualification Processing in the Shielded Cells, SRNL-L3100-2010-00028, SRNL, Aiken, SC, 29808 (February 2010). 
SRNL-STI-2010-00173

Revision 0

Appendix A - Other Data 
The SRAT product elemental composition is given in Table A-1 on a calcined basis. Anions, solids, $\mathrm{pH}$, and density are given in Table A-2.

Table A-1. SRAT product elemental wt \%'s calcined at $1100{ }^{\circ} \mathrm{C}$

\begin{tabular}{|c|c|c|c|c|}
\hline & SB6-12 & SB6-13 & SB6-14 & SB6-15 \\
\hline $\mathrm{Al}$ & 17.3 & 16.9 & 17.7 & 17.3 \\
\hline $\mathrm{Ba}$ & 0.119 & 0.119 & 0.119 & 0.118 \\
\hline $\mathrm{Ca}$ & 0.813 & 0.790 & 0.750 & 0.783 \\
\hline $\mathrm{Ce}$ & 0.100 & 0.097 & 0.104 & 0.103 \\
\hline $\mathrm{Cr}$ & 0.278 & 0.277 & 0.267 & 0.264 \\
\hline $\mathrm{Fe}$ & 18.8 & 18.4 & 16.3 & 16.1 \\
\hline $\mathrm{K}$ & 0.135 & 0.097 & 0.089 & 0.099 \\
\hline $\mathrm{La}$ & 0.091 & 0.090 & 0.090 & 0.090 \\
\hline $\mathrm{Mg}$ & 0.368 & 0.362 & 0.354 & 0.357 \\
\hline $\mathrm{Mn}$ & 8.93 & 8.61 & 7.59 & 7.41 \\
\hline $\mathrm{Na}$ & 13.6 & 13.1 & 15.2 & 15.9 \\
\hline $\mathrm{Ni}$ & 2.55 & 2.51 & 2.05 & 2.02 \\
\hline $\mathrm{P}$ & $<0.100$ & $<0.100$ & $<0.100$ & $<0.100$ \\
\hline $\mathrm{Pb}$ & $<0.010$ & $<0.010$ & 0.0 & 0.0 \\
\hline $\mathrm{S}$ & 0.350 & 0.353 & 0.330 & 0.338 \\
\hline $\mathrm{Si}$ & 1.18 & 1.12 & 1.20 & 1.18 \\
\hline $\mathrm{Ti}$ & $<0.010$ & $<0.010$ & $<0.010$ & $<0.010$ \\
\hline $\mathrm{Zn}$ & 0.081 & 0.080 & 0.078 & 0.077 \\
\hline $\mathrm{Zr}$ & 0.269 & 0.267 & 0.267 & 0.265 \\
\hline
\end{tabular}

Table A-2. Additional SRAT product properties

\begin{tabular}{|l|r|r|r|r|}
\hline & SB6-12 & SB6-13 & SB6-14 & SB6-15 \\
\hline wt $\%$ total solids & $22.89 \%$ & $21.05 \%$ & $22.30 \%$ & $22.15 \%$ \\
\hline wt\% insoluble solids & $13.96 \%$ & $11.96 \%$ & $13.41 \%$ & $12.67 \%$ \\
\hline wt\% soluble solids & $8.93 \%$ & $9.09 \%$ & $8.89 \%$ & $9.48 \%$ \\
\hline wt\% calcined solids & $15.79 \%$ & $14.36 \%$ & $15.35 \%$ & $14.91 \%$ \\
\hline \hline Slurry density, g/mL & 1.113 & 1.168 & 1.136 & 1.134 \\
\hline Supernate density, g/mL & 1.067 & 1.069 & 1.069 & 1.071 \\
\hline pH at $25 \mathrm{C}$ & 8.57 & 8.21 & 8.14 & 8.08 \\
\hline Fluoride, $\mathrm{mg} / \mathrm{kg}$ & $<100$ & $<100$ & $<100$ & $<100$ \\
\hline Chloride, $\mathrm{mg} / \mathrm{kg}$ & 486 & 403 & 451 & 460 \\
\hline Nitrite, $\mathrm{mg} / \mathrm{kg}$ & $<100$ & $<100$ & $<100$ & $<100$ \\
\hline Nitrate, $\mathrm{mg} / \mathrm{kg}$ & 17,000 & 20,350 & 18,500 & 20,100 \\
\hline Sulfate, $\mathrm{mg} / \mathrm{kg}$ & 185 & $<100$ & 158 & 220 \\
\hline Formate, $\mathrm{mg} / \mathrm{kg}$ & 49,300 & 49,600 & 48,750 & 50,800 \\
\hline Phosphate, $\mathrm{mg} / \mathrm{kg}$ & $<100$ & $<100$ & $<100$ & $<100$ \\
\hline
\end{tabular}

The SME product elemental composition is given in Table A-3 on a calcined basis. Anions, solids, $\mathrm{pH}$, and density are given in Table A-4. 
Table A-3. SME product elemental wt \%'s calcined at $1100{ }^{\circ} \mathrm{C}$

\begin{tabular}{|l|c|c|c|c|}
\hline & SB6-12 & SB6-13 & SB6-14 & SB6-15 \\
\hline $\mathrm{Al}$ & 6.33 & 6.38 & 6.24 & 6.23 \\
\hline $\mathrm{B}$ & 1.55 & 1.58 & 1.63 & 1.63 \\
\hline $\mathrm{Ba}$ & 0.042 & 0.041 & 0.044 & 0.043 \\
\hline $\mathrm{Ca}$ & 0.360 & 0.341 & 0.288 & 0.286 \\
\hline $\mathrm{Ce}$ & 0.037 & 0.037 & 0.041 & 0.041 \\
\hline $\mathrm{Cr}$ & 0.103 & 0.104 & 0.112 & 0.113 \\
\hline $\mathrm{Fe}$ & 5.97 & 5.78 & 5.78 & 5.78 \\
\hline $\mathrm{K}$ & 0.087 & 0.071 & 0.051 & 0.053 \\
\hline $\mathrm{La}$ & 0.032 & 0.032 & 0.033 & 0.033 \\
\hline $\mathrm{Li}$ & 2.37 & 2.35 & 2.32 & 2.32 \\
\hline $\mathrm{Mg}$ & 0.134 & 0.131 & 0.137 & 0.138 \\
\hline $\mathrm{Mn}$ & 2.82 & 2.71 & 2.73 & 2.74 \\
\hline $\mathrm{Na}$ & 9.43 & 9.44 & 9.59 & 9.49 \\
\hline $\mathrm{Ni}$ & 0.668 & 0.664 & 0.700 & 0.704 \\
\hline $\mathrm{P}$ & $<0.100$ & $<0.100$ & $<0.100$ & $<0.100$ \\
\hline $\mathrm{Pb}$ & $<0.010$ & $<0.010$ & 0.014 & 0.015 \\
\hline $\mathrm{S}$ & 0.115 & 0.109 & 0.113 & 0.114 \\
\hline $\mathrm{Si}$ & 23.25 & 23.00 & 23.85 & 23.75 \\
\hline $\mathrm{Ti}$ & $<0.010$ & $<0.010$ & $<0.010$ & $<0.010$ \\
\hline $\mathrm{Zn}$ & 0.036 & 0.035 & 0.029 & 0.027 \\
\hline $\mathrm{Zr}$ & 0.101 & 0.101 & 0.103 & 0.103 \\
\hline
\end{tabular}

Table A-4. Additional SME product properties

\begin{tabular}{|l|c|c|c|c|}
\hline & SB6-12 & SB6-13 & SB6-14 & SB6-15 \\
\hline wt\% total solids & $44.36 \%$ & $42.60 \%$ & $45.12 \%$ & $44.97 \%$ \\
\hline $\mathrm{wt} \%$ insoluble solids & $35.83 \%$ & $33.54 \%$ & $36.48 \%$ & $36.41 \%$ \\
\hline $\mathrm{wt} \%$ soluble solids & $8.53 \%$ & $9.05 \%$ & $8.64 \%$ & $8.57 \%$ \\
\hline $\mathrm{wt} \%$ calcined solids & $38.13 \%$ & $36.45 \%$ & $38.94 \%$ & $38.75 \%$ \\
\hline \hline Slurry density, g/mL & 1.344 & 1.318 & 1.343 & 1.364 \\
\hline Supernate density, g/mL & 1.083 & 1.088 & 1.086 & 1.089 \\
\hline \hline $\mathrm{pH}$ at $25 \mathrm{C}$ & 6.95 & 7.51 & 8.01 & 8.03 \\
\hline Fluoride, $\mathrm{mg} / \mathrm{kg}$ & $<100$ & $<100$ & $<100$ & $<100$ \\
\hline Chloride, $\mathrm{mg} / \mathrm{kg}$ & 411 & 352 & 399 & 400 \\
\hline Nitrite, $\mathrm{mg} / \mathrm{kg}$ & $<100$ & $<100$ & $<100$ & $<100$ \\
\hline Nitrate, $\mathrm{mg} / \mathrm{kg}$ & 13,300 & 16,050 & 16,300 & 17,200 \\
\hline Sulfate, $\mathrm{mg} / \mathrm{kg}$ & $<100$ & $<100$ & 119 & 171 \\
\hline Formate, $\mathrm{mg} / \mathrm{kg}$ & 43,100 & 43,700 & 46,300 & 46,700 \\
\hline Phosphate, $\mathrm{mg} / \mathrm{kg}$ & $<100$ & $<100$ & $<100$ & $<100$ \\
\hline
\end{tabular}

The $\mathrm{pH}$ profiles from the four SRAT cycles are shown in Figure A-1. The probes held calibration to within $0.4 \mathrm{pH}$ units in three of the four runs, but the probe in SB6-14 was over one $\mathrm{pH}$ unit out of calibration by the end of the SME cycle. The recorded SB6-14 pH data were corrected assuming a linear drift in calibration with time, but the $\mathrm{pH}$ data should not be considered of high 
quality for this run. The $\mathrm{SB} 6-14 \mathrm{pH}$ trace is shown as a dashed line rather than as a continuous line because of the calibration issues.

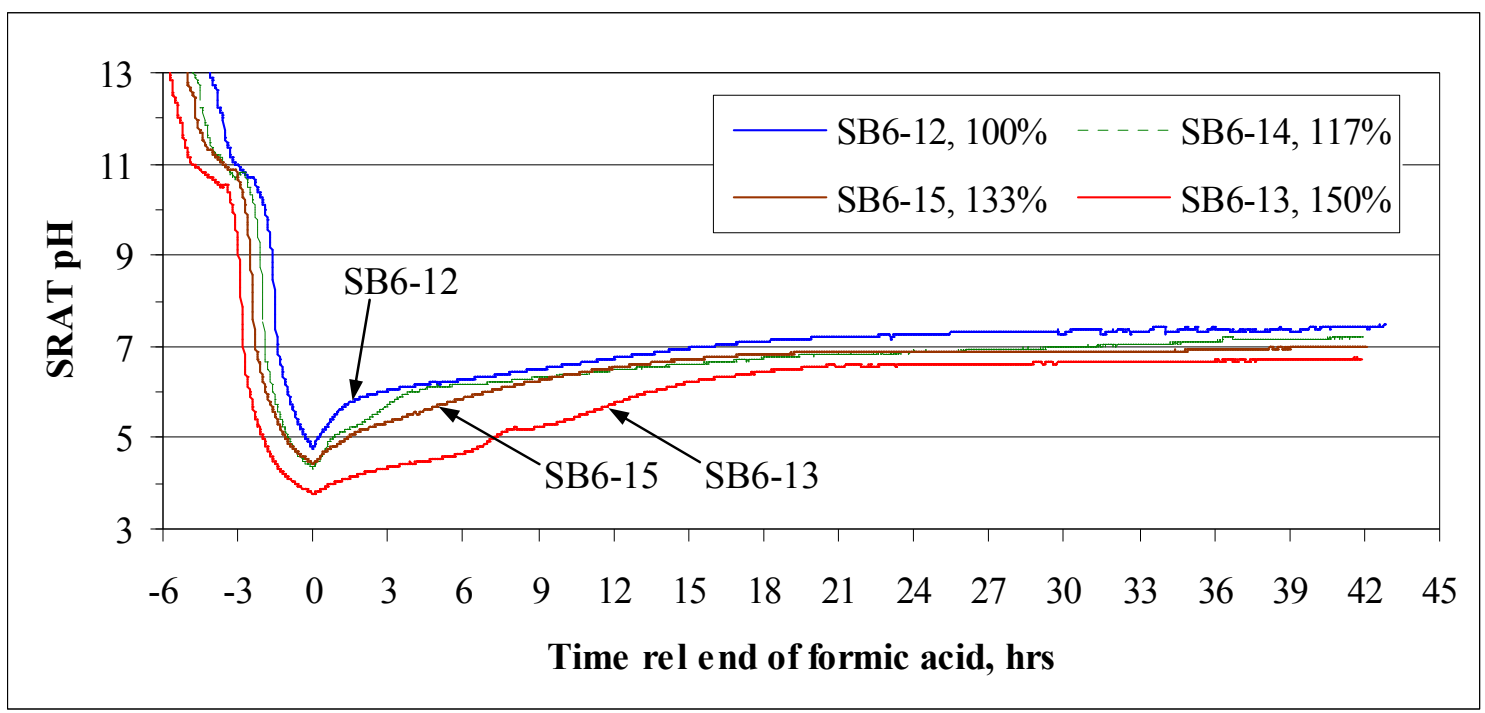

Figure A-1. The SRAT pH profiles for the four tests

The sequence of dropping $\mathrm{pH}$ values prior to the end of acid addition reflects the staggered starts of the four runs with decreasing acid stoichiometry (the total acid addition time increased with increasing stoichiometry). The minimum $\mathrm{pH}$, obtained at the end of formic acid addition, ranged from 3.8-4.8. The SRAT product slurry $\mathrm{pH}$ values ranged from 6.7-7.5 when taken at the operating temperature of about $101{ }^{\circ} \mathrm{C}$. The corresponding range after cooling to room temperature was from 8.1-8.6.

Data on the SRAT boil-up rate were obtained and logged during these runs. Each step change represents a new measurement of the boil-up rate.

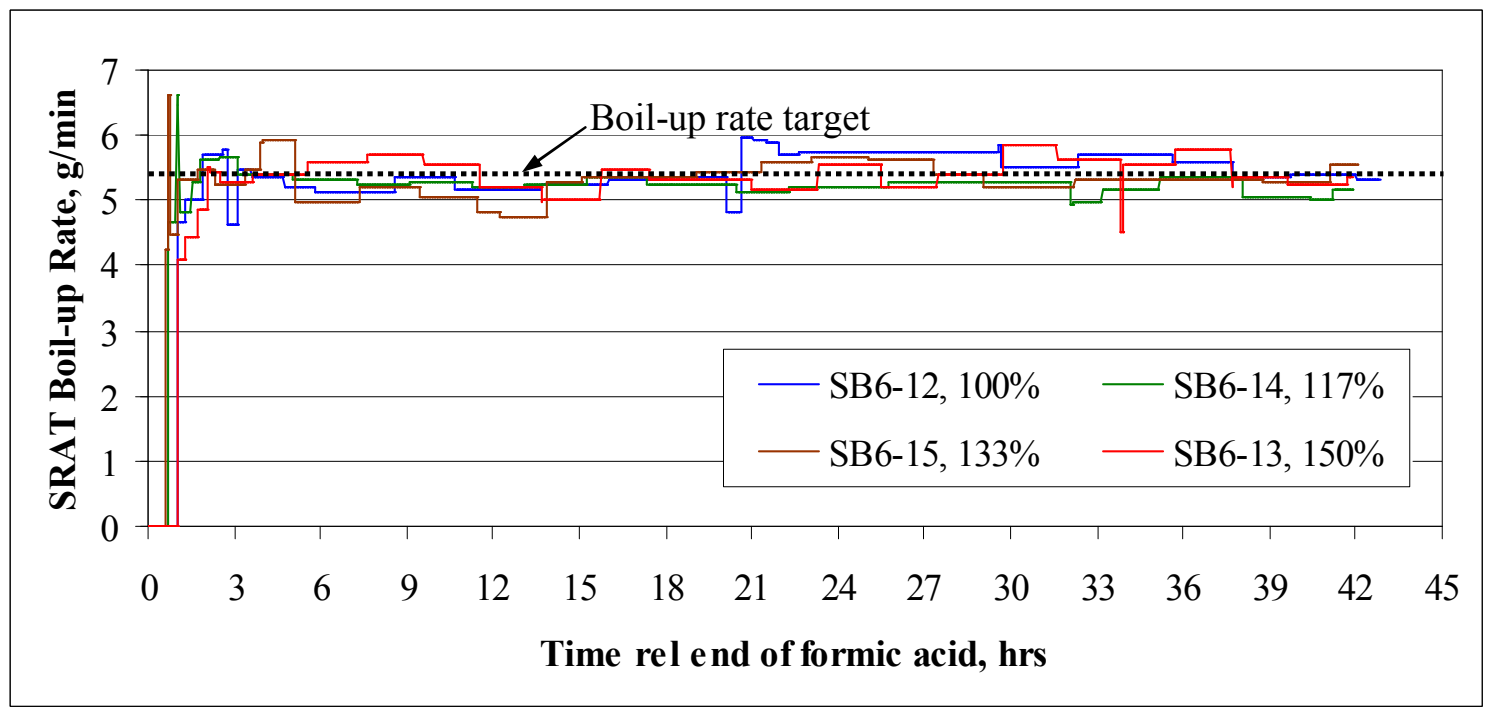

Figure A-2. The SRAT boil-up rate measurement data 
The target boil-up rate was $5.4 \mathrm{~g} / \mathrm{min}$, corresponding to $5,000 \mathrm{lbs} / \mathrm{hr}$ in DWPF. Boil-up rates were regularly monitored in the past, but the calculations were done off-line. Now the calculations are performed on the SRAT PC control computer, and the results are logged with the other process data. This enhancement was made to support efforts to study steam stripping of mercury during the SRAT cycle.

An oxidation-reduction probe (ORP) was present during SB6-13 and SB6-15 in the SRAT slurry measuring the relative millivolt potential of the supernate. Standard solutions indicate that the probe was reading high by about $50 \mathrm{mV}$ in both runs, i.e. the curves could be shifted down by about $50 \mathrm{mV}$ to approximate absolute $\mathrm{mV}$ rather than relative $\mathrm{mV}$. Positive $\mathrm{mV}$ are reducing potentials and negative $\mathrm{mV}$ are oxidizing potentials. The ORP readings around the time of acid addition and dewatering are shown in Figure A-3. The horizontal line at $-50 \mathrm{mV}$ represents the approximate offset of the relative and absolute potentials.

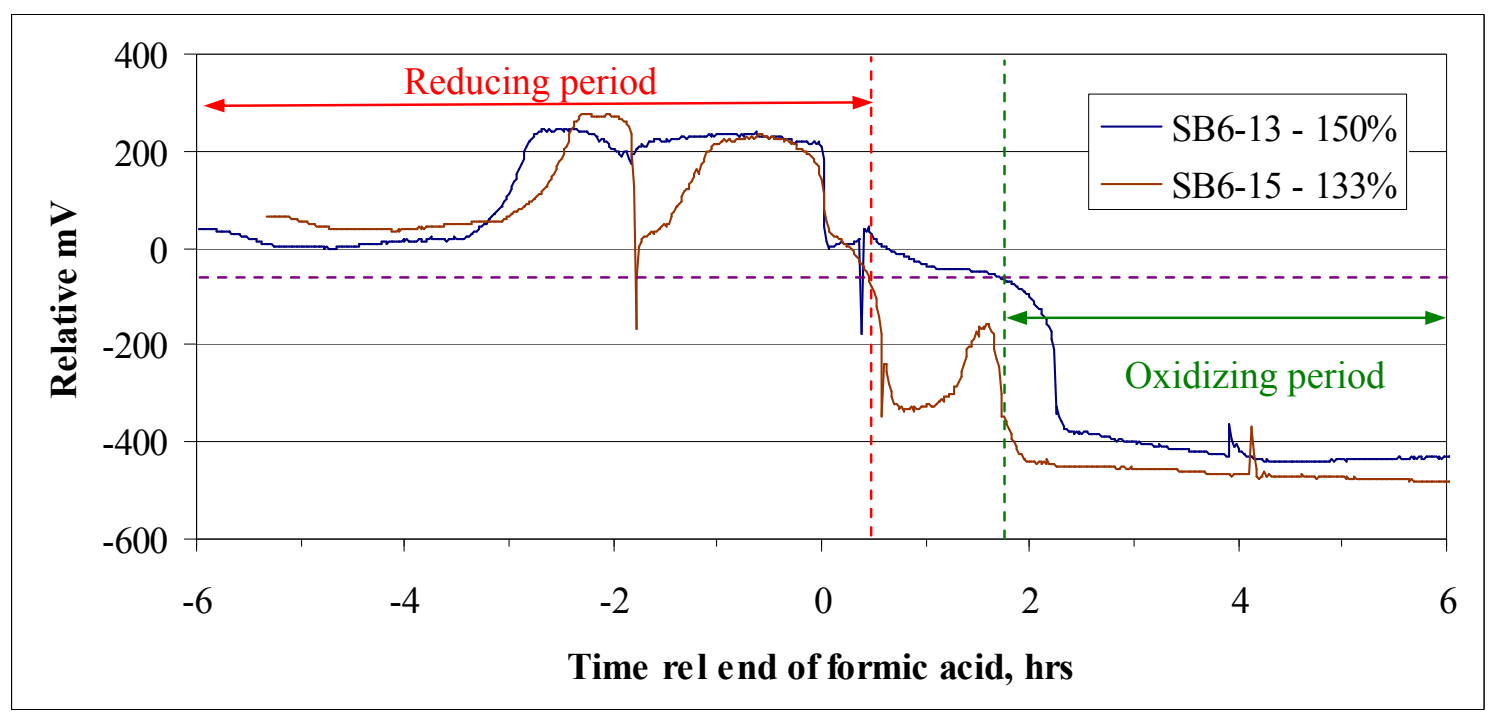

Figure A-3. Oxidation-reduction potential of the SRAT around the time of acid addition.

Small reductions in potential were observed during nitric acid (oxidizer) addition. The initial trend reversed after formic acid addition was initiated. SB6-13 (150\%) had a $200 \mathrm{mV}$ drop right after formic acid addition and prior to hydrogen generation. SB6-15 (133\%) had a similar drop, followed shortly thereafter by a second drop of $250 \mathrm{mV}$. SB6-13 matched that drop two hours later. The reason for the delay is not presently known, but perhaps it took that long to destroy enough of the extra formic acid in SB6-13 to make it act like SB6-15. Two small blips in the potential at about four hours coincide with the onset of reflux. ORP data were taken to the end of the SRAT cycle, but there were no features to observe in the 36 hours not shown. 


\section{Distribution:}
A. B. Barnes, 999-W
D. A. Crowley, 773-43A
S. D. Fink, 773-A
B. J. Giddings, 786-5A
C. C. Herman, 999-W
S. L. Marra, 773-A
F. M. Pennebaker, 773-42A
J. H. Scogin, 773-A
W. R. Wilmarth, 773-A
C. J. Bannochie, 773-42A
J. M. Bricker, 704-27S
T. L. Fellinger, 704-26S
A. I. Fernandez, 999-W
J. M. Gillam, 766-H
B. A. Hamm, 766-H
E. W. Holtzscheiter, 704-15S
J. F. Iaukea, 704-30S
M. T. Keefer, 766-H
D. P. Lambert, 999-W
R. T. McNew, 704-27S
J. D. Newell, 999-W
J. E. Occhipinti, 704-S
J. M. Pareizs, 773-A
D. K. Peeler, 999-W
B. R. Pickenheim,, 999-W
J. W. Ray, 704-S
S. H. Reboul, 773-A
H. B. Shah, 766-H
D. C. Sherburne, 704-S
M. E. Stone, 999-W
J. R. Zamecnik, 999-W 